\title{
Intensional Noun Phrases with know and be
}

\section{Maribel Romero}

University of Pennsylvania. Department of Linguistics

610 Williams Hall

Philadelphia, PA 19104 USA

romero@ling.upenn.edu

\begin{abstract}
Following Romero (2003), this paper develops a unified analysis of two types of N(oun) P(hrase)s: concealed question NPs with know and NP subjects of specificational sentences with be. It is argued that both epistemic know and specificational be are intensional verbs requiring an intensional semantic argument. It is further argued that this semantic argument is, in both cases, propositional in nature. Crosslinguistic data on pronominalization, coordination and matching effects in free relatives are provided in support of these conclusions.
\end{abstract}

Key words: concealed question, specificational copular sentence, intensionality, connectivity, pronominalization, gender, coordination, matching effects.

\section{Table of Contents}

1. Introduction

2. A Unified Intensional Analysis of CQs and SSs
3. Data in support of implementation (ii)

4. Conclusions

References

\section{Introduction}

This paper is concerned with two kinds of Noun Phrases (NPs): concealed question NPs with know-type verbs and specificational subject NPs with $b e$.

The underlined NPs in (1) are called 'concealed question NPs' (CQs, henceforth) because sentences that embed them typically convey the same truth-conditional meaning as the corresponding versions with an embedded interrogative, as illustrated in (2) (Heim 1979):

(1) a. John knows Bill's telephone number.

b. They announced the winner of the contest.

* I am indebted to Rajesh Bhatt, Dave Embick, Irene Heim, Caroline Heycock, Anthony Kroch, Line Mikkelsen, Chris Potts and two anonymous reviewers for helpful comments and discussion at different stages of the paper. Many thanks to my informants Martin Kappus (German), Elsi Kaiser (Finnish) and Sophia Malamud (Russian) and to my countless informants for English. 
(2) a. John knows what Bill's telephone number is.

b. They announced who won the contest.

Specificational Subjects (SSs, henceforth) are the pre-verbal NPs of (non-inverted) specificational copular sentences. Copular sentences can be divided into at least two groups: predicational sentences and specificational sentences (Higgins 1973). Intuitively, in predicational sentences the post-verbal XP's denotation is predicated of the subject's denotation, as in (3), whereas in specificational sentences «the Subject [MR: underlined] in some way delimits a domain and the specificational predicate determines a member of that domain» (Higgins 1973:132), as in (4).

(3) The number of planets is large.

PREDICATIONAL

(4) The number of planets is nine.

SPECIFICATIONAL

Furthermore, predicational and specificational copular sentences differ grammatically with respect to so-called connectivity effects (Akmajian 1970, Higgins 1973, Jacobson 1994, Sharvit 1999). Here we will only illustrate two types of connectivity effects: Binding Theory and variable binding. Binding Theory dictates that a name cannot be c-commanded by a co-indexed expression (principle C), and that a reflexive must be locally c-commanded by a co-indexed expression (principle A) (Chomsky 1986:166ff.), as shown in (5). This analysis straighforwardly applies to the predicational sentences in (6), in which the co-indexed NP $h e_{1}$ does not c-command outside the Relative Clause. But some extra assumptions are needed to account for the specificational sentences in (7), in which principle $C$ is violated and principle A is satisfied despite the apparent lack of c-command from the embedded subject he ${ }_{1}$ to John / himself $_{1}$ :
a. $\mathrm{He}_{1}$ likes $\mathrm{John}_{* 1 / 2}$.
b. (Paul thinks $)$ he $_{1}$ likes himself ${ }_{1 / * 2}$.

(6) a. The person that he ${ }_{1}$ likes best is nice to $\mathrm{John}_{1}$.

b. * The person that he ${ }_{1}$ likes best is nice to himself $_{1}$.

(7) a. * The person that he ${ }_{1}$ likes best is $\mathrm{John}_{1}$.

b. The person that he ${ }_{1}$ likes best is himself . $_{1}$

In similar fashion, a binder must c-command its bindee at Logical Form, as shown in (8) (see e.g. Heim-Kratzer 1998). This condition, together with the assumption that a quantifier cannot Q(uantifier) R(aise) out of a complex NP island, is able to account for the fact that variable binding does not obtain in the predicational sentence (9a), as shown in its $\mathrm{L}$ (ogical) $\mathrm{F}$ (orm) representation (9b). In contrast, variable binding is possible in the specificational sentence (10a) despite the 
impossibility of LF c-command from no boy to his in (10b). Again, further assumptions are needed to explain specificational structures.
a. No boy ${ }_{1}$ 's pet acknowledged him ${ }_{1}$.

b. LF: $\left[{ }_{I P}\right.$ No boy $_{1}\left[{ }_{I P} t_{1}\right.$ 's pet aknowledged him $\left.\left.{ }_{1}\right]\right]$

(9) a. * The woman no boy ${ }_{1}$ saw was interested in him 1 .

b. LF: $\left[_{\mathrm{NP}-\text { Island }}\right.$ The woman $\left[{ }_{\mathrm{CP}} \text { (that }\right)_{2}$ no boy ${ }_{1}$ saw $\left.\left.\mathrm{t}_{2}\right]\right]$ was interested in him ${ }_{1}$.

(10) a. The woman no boy ${ }_{1}$ saw was his ${ }_{1}$ mother.

b. LF: $\left[_{\mathrm{NP}-\text { Island }}\right.$ The woman $\left[\mathrm{CP}_{\mathrm{CP}}(\text { that })_{2}\right.$ no boy $_{1}$ saw $\left.\left.\mathrm{t}_{2}\right]\right]$ was his ${ }_{1}$ mother.

Romero (2003) argues for a unified analysis of CQs and SSs that sets them apart from regular NPs in extensional contexts. In particular, Romero shows that, in the same way that verbs like know taking CQs are intensional with respect their CQ argument, so is specificational be intensional with respect to its SS. She spells out one possible implementation of her unified intensional analysis -implementation (i)-, but she also mentions a second implementation -implementation (ii)- as a possible alternative. In implementation (i), know and specificational be combine directly with the semantic contribution of the NP. In implementation (ii), the NP combines with an ANS(wer) operator -comparable to those proposed for interrogative clauses in Heim (1994) and Beck-Rullmann (1999)-, yielding a propositional concept, and this propositional concept is the argument of know and be. Romero (2003) leaves the choice of one implementation over the other for future research.

The goal of this paper is two-fold. First, the paper provides further support for a unified analysis of CQs and SSs. Second, it presents evidence in favor of implementation (ii), where the arguments of know and be are the complexes ANS(CQ) and ANS(SS), which have a propositional nature. To this end, three grammatical characteristics will be discussed. The first piece of data concerns pronominal reference to CQs and SSs in languages with an (at least partially) referentially based gender system, like English and Finnish. Coordination of verbs taking CQs/SSs with verbs that do not take CQs/SSs gives rise to the second empirical pattern, tested in non-pro-drop languages like English, German, Finnish and Russian. Finally, the so-called matching effects in Catalan and Spanish free relatives (from HirschbühlerRivero $(1983 a, b))$ will be examined. These three sets of data provide further arguments for a unified analysis of CQs and SSs and will be shown to support implementation (ii) over implementation (i).

The paper is organized as follows. Section 2 presents Romero's (2003) unified analysis of CQs with know and SSs with be as well as its two possible implementations, providing new crosslinguistic examples and developing the analysis further in the points relevant to the present discussion. Section 3 presents the three aforementioned sets of data. The data on pronominal reference are presented in subsection 3.1; the coordination data are introduced in subsection 3.2; and sub- 
section 3.3 discusses the impact of the matching effects observed in the literature on the choice of implementation (ii). Section 4 concludes.

\section{A Unified Intensional Analysis of CQs and SSs}

\subsection{Heim's (1979) ambiguity for CQs}

Following Karttunen (1977), an interrogative clause expresses a function from worlds to the set of true answers to that interrogative in that world. This is illustrated in (11). This function then combines with the denotation of (strongly exhaustive) know in Heim (1994), given in (12), to yield the truth conditions of sentence (13), spelled out in (14). Roughly, (14) states that John knows in w who spoke if and only if, for all his belief worlds w', the set of true answers to this question in the belief world w' is exactly the same as the set of true answers in the actual world w.

(11) $[[$ who spoke $]]=\lambda \mathrm{w} .\left\{\mathrm{p}: \mathrm{p}(\mathrm{w}) \& \exists \mathrm{x}\left[\mathrm{p}=\lambda \mathrm{w}^{\prime \prime} . \operatorname{spoke}(\mathrm{x}, \mathrm{w} ")\right]\right\}$

(Karttunen 1977)

$$
\left[\left[k_{n o w}\right]\right]=\lambda \mathrm{q}_{\langle\mathrm{s},\langle<\mathrm{s}, \mathrm{t}\rangle, \mathrm{t}\rangle} \lambda \mathrm{x}_{\mathrm{e}} \lambda \mathrm{w} \cdot \forall \mathrm{w}^{\prime} \in \operatorname{Dox}_{\mathrm{x}}(\mathrm{w})\left[\mathrm{q}\left(\mathrm{w}^{\prime}\right)=\mathrm{q}(\mathrm{w})\right]
$$

(13) John knows who spoke.

(14) $[[$ John knows who spoke $]]=\lambda \mathrm{w} . \forall \mathrm{w}^{\prime} \in \operatorname{Dox}_{\mathrm{j}}(\mathrm{w})$

$\left[\left\{\mathrm{p}: \mathrm{p}\left(\mathrm{w}^{\prime}\right) \& \exists \mathrm{x}\left[\mathrm{p}=\lambda \mathrm{w}^{\prime \prime} . \operatorname{spoke}\left(\mathrm{x}, \mathrm{w}^{\prime \prime}\right)\right]\right\}=\left\{\mathrm{p}: \mathrm{p}(\mathrm{w}) \& \exists \mathrm{x}\left[\mathrm{p}=\lambda \mathrm{w}^{\prime \prime} . \operatorname{spoke}\left(\mathrm{x}, \mathrm{w}^{\prime \prime}\right)\right]\right\}\right]$

This analysis can easily be extended to simple concealed question NPs. The NP the capital of Italy, when functioning as a CQ, contributes an individual concept, i.e. a function from worlds to (possibly plural sums of) individuals. This individual concept can be spelled out as in (15a) or as in (15b). ${ }^{1}$ The concealed question counterpart of interrogative know is given in (16). When these combine in sentence (17), we obtain the truth-conditions in (18). In a way parallel to (14), the formula (18) states that John knows in w the capital of Italy if and only if, for all of John's doxastic alternatives $\mathrm{w}^{\prime}$, the value of this individual concept in $\mathrm{w}^{\prime}$ is exactly what is it is in the actual world w.

1. In (15a), capital-of-Italy is a 2-place predicate over individual - world pairs. In (15b), capital-ofItaly is a 2-place predicate over individual concept - world pairs, which applies truly to a pair $\left\langle\underline{\mathrm{x}}_{\langle\mathrm{s}, \mathrm{e}}, \mathrm{w}\right\rangle$ iff it is true in $\mathrm{w}$ that, for all the $\mathrm{w}^{\prime \prime} \in \operatorname{Dom}(\underline{\mathrm{x}}), \underline{\mathrm{x}}\left(\mathrm{w}^{\prime \prime}\right)$ has the property of being the capital of Italy in $\mathrm{w}^{\prime \prime}$. We will use the second notation to make it more parallel to the formal translation of know in (16), which applies to an individual concept and a world (and to the denotation of the subject). (Later, we will see that know can also take an individual concept concept, and we will correspondingly allow for this possibility in the head noun as well.) The choice of notation for the head noun has no impact on the arguments presented in the present paper regarding the intensionality of know. 
(15) Semantic contribution of the CQ [the capital of Italy]:

a. $\lambda w \cdot \mathrm{x}_{\mathrm{e}}$ [capital-of-Italy $\left.(\mathrm{x}, \mathrm{w})\right]$ or

b. $\quad \underline{\underline{x}} \underline{\langle s, e>}_{c}[$ capital-of-Italy $(\underline{x}, w)]$

(16) $\left[\left[k_{\text {no }} w_{\mathrm{CQ}}\right]\right]=\lambda \mathrm{y}_{<\mathrm{s}, \mathrm{e}\rangle} \lambda \mathrm{x}_{\mathrm{e}} \lambda \mathrm{w} . \forall \mathrm{w}^{\prime} \in \operatorname{Dox}_{\mathrm{x}}(\mathrm{w})\left[\mathrm{y}\left(\mathrm{w}^{\prime}\right)=\mathrm{y}(\mathrm{w})\right]$

(17) John knows the capital of Italy.

(18) $[[$ John knows the capital of Italy $]]=$

$$
\begin{aligned}
& \lambda \mathrm{w} . \forall \mathrm{w}^{\prime} \in \operatorname{Dox}_{\mathrm{j}}(\mathrm{w})\left[\underline{\mathrm{x}}_{\langle\mathrm{s}, \mathrm{e}\rangle}[\operatorname{capital}-o f-\operatorname{Italy}(\underline{\mathrm{x}}, \mathrm{w})]\left(\mathrm{w}^{\prime}\right)=\right. \\
& \left.\underline{\underline{x}} \underline{\langle s, e\rangle}_{\langle}[\text {capital-of-Italy }(\underline{x}, w)](w)\right]
\end{aligned}
$$

With this background, Heim (1979) presents an interesting ambiguity for nested CQs. A sentence like (19) has two readings, which we will call reading A and reading B. Reading A, described in (20), can be unambiguously paraphrased as 'John knows the same price that Fred knows'.

(19) John knows the price that Fred knows.

(Heim 1979)

(20) Reading A: 'John knows the same price that Fred knows.'

There are several relevant questions about prices:

«How much does the milk cost?»

«How much does the oil cost?»

«How much does the ham cost?»

Fred knows the answer to exactly one of these questions, e.g., to the first one. John knows the answer to this question too.

The second reading of (19), reading B, is described in (21) and can be unambiguously paraphrased as 'John knows what price Fred knows'.

(21) Reading B: 'John knows what price Fred knows.'

There are several relevant questions about prices:

«How much does the milk cost?»

«How much does the oil cost?»

«How much does the ham cost?»

Fred knows the answer to one of these questions, e.g., to «How much does the milk cost?».

Then, there is the «meta-question» asking which of these questions is the one whose answer Fred knows.

John knows the answer to the meta-question. I.e., John knows that the question about prices whose answer Fred knows is «How much does the milk cost?». 
The ambiguity that Heim observed for English is attested in other languages as well, like Catalan and German. Both (22) and (23) are ambiguous between reading $\mathrm{A}$ and reading $\mathrm{B}$.

En Joan sap el preu que sap en Pere.

(Catalan)

The Joan knows the price that knows the Pere

'Joan knows the price that Pere knows.'

(23) Jonas erinnert sich an den Preis, den Peter erraten hat.

(German)

Jonas remembers REFL PREP the price that Peter guessed has 'Jonas remembers the price that Klaus guessed.'

\subsection{Romero's (2003) analysis of the ambiguity of CQs. Implementations (i) and (ii)}

Romero (2003) shows that using exclusively the extension of the NP the price that Fred knows cannot capture the desired ambiguity. She then compares know with intensional verbs like look for, which take an intensional object as their argument (e.g., Zimmermann 1992, Moltmann 1997). This intensional object is often provided by the intension of its complement NP, as exemplified in (24). But this intensional object can also arise from the extension of a higher type NP. This second possibility is illustrated in (25), which has a de dicto reading on the extension of the NP that makes the sentence true in scenario (26):

(24) John is looking for the unicorn with the longest horn.

'In all of John's bouletic alternatives $\mathrm{w}^{\prime}$ in w: John finds in $\mathrm{w}^{\prime}$ the individual that is the unicorn with the longest horn in $\mathrm{w}^{\prime}$ (whichever that may be).'

$\Rightarrow$ look for takes as its argument the INTENSION of the NP.

(25) John is looking for the unicorn Fred is looking for (: the one with the longest horn.)

'Each $\mathrm{x}$ out of John and Fred is such that, in all of x's bouletic alternatives w' in $\mathrm{w}$ : $\mathrm{x}$ finds in $\mathrm{w}^{\prime}$ the individual that is the unicorn with the longest horn in $\mathrm{w}^{\prime}$ (whichever that may be).'

$\Rightarrow$ look for takes as its argument the EXTENSION of the NP, which is an intensional object.

(26) Scenario:

John does not have any beliefs as to which unicorn has the longest horn. He wants to catch the unicorn with the longest horn, whichever that may be. Exactly the same holds for Fred.

It is then argued that the reading A / reading B ambiguity is nothing more than the possibility of drawing an intensional object from the extension or from the intension of the NP. Reading A results when this intensional object corresponds to 
the extension of the NP. Reading B obtains when the intensional object arises from the intension of the NP. This is summarized in (27):

(27) John knows the price that Fred knows.

a. Reading A: [[know $]]+$ EXTENSION of $\int_{N P}$ the price that Fred knows].

b. Reading B: [[know $]]+$ INTENSION of $\int_{N P}$ the price that Fred knows].

This analysis of the reading A / reading B ambiguity can be implemented in two ways. Under the first implementation, given in Romero (2003), the intensional object $\underline{x}$ corresponding to the extension or intension of the NP is the direct semantic argument of the verb know. This is syntactically represented in (28). Under the second implementation, the intensional object is the argument of an answer operator ANS, and the value of ANS applied to $\underline{x}, \operatorname{ANS}(\underline{x})$, is the semantic argument of know. The corresponding syntactic representation is sketched in (29). We will consider each implementation in turn.

(28) Implementation (i):

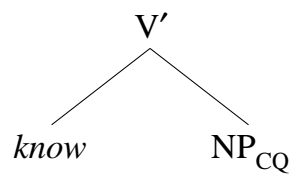

(29) Implementation (ii):

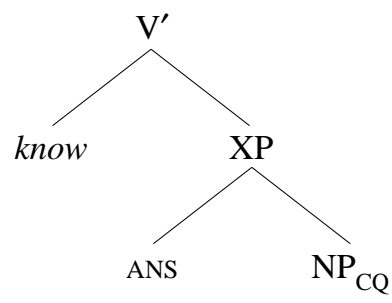

The tree in (30) shows the semantic computation of the concealed question NP step by step: ${ }^{2}$

2. For simplicity, the internal computation of the embedded $\left[{ }_{I P}\right.$ Fred knows $\left.t_{5}\right]$ is not shown. Implementations (i) and (ii) would have to apply here as well, but, as they yield the same semantic result, it is enough to illustrate them for matrix know. 
(30) $\left[[\text { the price that Fred knows] }]^{\mathrm{g}}=\right.$

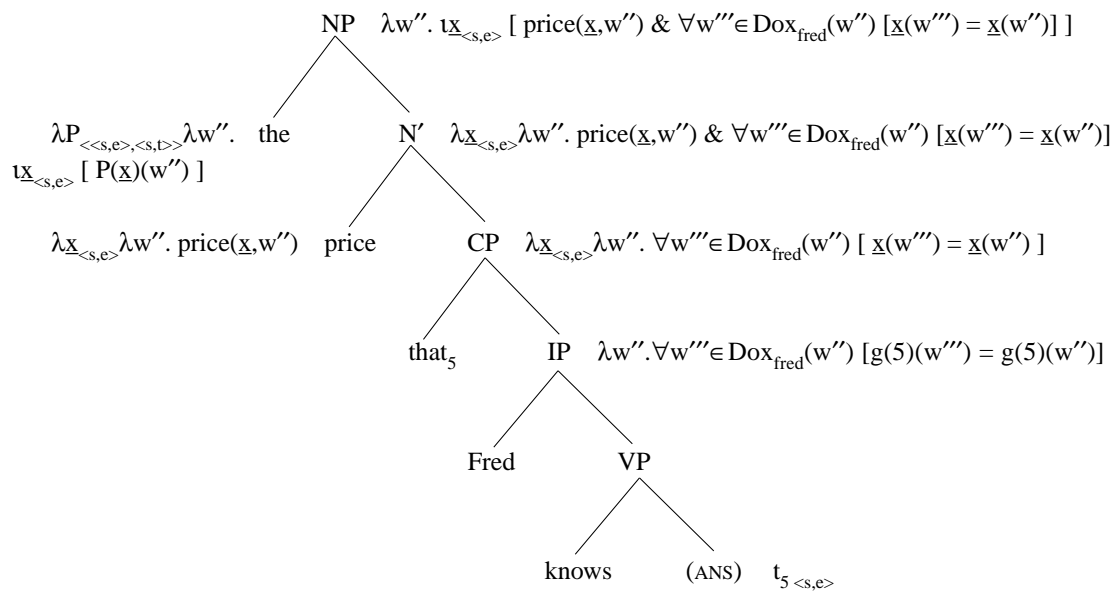

$\mathrm{g}(5)$

In implementation (i), we combine the extension or intension of the NP with the lexical entry of know $_{\mathrm{CQ}}$ in (31), where $\mathrm{y}$ is a variable of type $\langle\mathrm{s}$, e $\rangle$ or $<\mathrm{s},\langle\mathrm{s}, \mathrm{e}\rangle>$. The two readings of (32) are obtained as follows. In reading A, the extension of the NP at the evaluation world $\mathrm{w}-[[\mathrm{NP}]]^{\mathrm{g}}(\mathrm{w})$, an intensional object itself, of type <s,e>- is fed as the argument of know, as shown in (33): ${ }^{3}$

$$
\left[\left[k_{\mathrm{CQ}}\right]\right]=\lambda \mathrm{y} \lambda \mathrm{x}_{\mathrm{e}} \lambda \mathrm{w} \cdot \forall \mathrm{w}^{\prime} \in \operatorname{Dox}_{\mathrm{x}}(\mathrm{w})\left[\mathrm{y}\left(\mathrm{w}^{\prime}\right)=\mathrm{y}(\mathrm{w})\right]
$$

(32) John knows the price that Fred knows.

\section{(33) Reading A:}

a. Extension of NP in w:

$$
\underline{\mathrm{x}}_{\langle\mathrm{s}, \mathrm{e}\rangle}\left[\operatorname{price}(\underline{\mathrm{x}}, \mathrm{w}) \& \forall \mathrm{w}^{\prime \prime \prime} \in \operatorname{Dox}_{\text {fred }}(\mathrm{w})\left[\underline{\mathrm{x}}\left(\mathrm{w}^{\prime \prime \prime}\right)=\underline{\mathrm{x}}(\mathrm{w})\right]\right]
$$

b. Know + extension of the NP:

$$
\begin{aligned}
& \lambda \mathrm{w} . \forall \mathrm{w}^{\prime} \in \operatorname{Dox}_{\mathrm{j}}(\mathrm{w}) \\
& {\left[\underline{\mathrm{x}} \underline{\mathrm{x}}_{\langle\mathrm{s}, \mathrm{e}\rangle}\left[\operatorname{price}(\underline{\mathrm{x}}, \mathrm{w}) \& \forall \mathrm{w}^{\prime \prime \prime} \in \operatorname{Dox}_{\text {fred }}(\mathrm{w})\left[\underline{\mathrm{x}}\left(\mathrm{w}^{\prime \prime \prime}\right)=\underline{\mathrm{x}}(\mathrm{w})\right]\right]\left(\mathrm{w}^{\prime}\right)=\right.} \\
& \left.\underline{\underline{\mathrm{x}}} \underline{\mathrm{w}}_{\langle\mathrm{s}, \mathrm{e}\rangle}\left[\operatorname{price}(\underline{\mathrm{x}}, \mathrm{w}) \& \forall \mathrm{w}^{\prime \prime \prime} \in \operatorname{Dox}_{\text {fred }}(\mathrm{w})\left[\underline{\mathrm{x}}\left(\mathrm{w}^{\prime \prime \prime}\right)=\underline{\mathrm{x}}(\mathrm{w})\right]\right](\mathrm{w})\right]
\end{aligned}
$$

3. The meaning of know that combines with the NP's extension (33a) to yield (33b) is slightly oversimplified in the text for expository purposes. Technically, we would need to assume that all natural language predicates -including the matrix know- come with a free world index that is later bound by some higher operator (see Farkas 1993, Percus 2000). Since we use the NP's extension in the actual (topmost) world, formal expressions corresponding to the predicates within the NP -price $(x, w)$ and $\operatorname{Dox}_{\text {fred }}(w)$ - get the same topmost world variable $w$ as formal expressions corresponding to the matrix know $-\operatorname{Dox}_{j}(w)$. 
The final truth-conditions in (33b) roughly state the following: we are in a world w such that the unique price $\left.\underline{x}_{\langle\mathrm{s}, \mathrm{e}}\right\rangle$ that Fred knows the value of in $\mathrm{w}$ is such that John too knows the value of $\underline{x}_{\langle s, e>}$ in w. Reading A is correctly rendered by these truth-conditions.

In reading $\mathrm{B}$, know takes the intension of the $\mathrm{NP}-[[\mathrm{NP}]]^{\mathrm{g}}$, of type $\langle\mathrm{s},\langle\mathrm{s}, \mathrm{e}>>-$, as shown in (34):

\section{(34) Reading B:}

a. Intension of the NP:

$$
\lambda \mathrm{w}^{\prime \prime} . \underline{\mathrm{x}}_{\langle\mathrm{s}, \mathrm{e}\rangle}\left[\operatorname{price}\left(\underline{\mathrm{x}}, \mathrm{w}^{\prime \prime}\right) \& \forall \mathrm{w}^{\prime \prime \prime} \in \operatorname{Dox}_{\mathrm{fred}}\left(\mathrm{w}^{\prime \prime}\right)\left[\underline{\mathrm{x}}\left(\mathrm{w}^{\prime \prime \prime}\right)=\underline{\mathrm{x}}\left(\mathrm{w}^{\prime \prime}\right)\right]\right]
$$

b. Know + intension of the NP:

$$
\begin{aligned}
& \lambda \mathrm{w} . \forall \mathrm{w}^{\prime} \in \operatorname{Dox}_{\mathrm{j}}(\mathrm{w}) \\
& {\left[\lambda \mathrm{w}^{\prime \prime} .1 \underline{\mathrm{x}}_{\langle\mathrm{s}, \mathrm{e}}\left[\mathrm{price}\left(\underline{\mathrm{x}}, \mathrm{w}^{\prime \prime}\right) \& \forall \mathrm{w}^{\prime \prime \prime} \in \operatorname{Dox}_{\mathrm{fred}}\left(\mathrm{w}^{\prime \prime}\right)\left[\underline{\mathrm{x}}\left(\mathrm{w}^{\prime \prime \prime}\right)=\underline{\mathrm{x}}\left(\mathrm{w}^{\prime \prime}\right)\right]\right]\left(\mathrm{w}^{\prime}\right)=\right.} \\
& \left.\lambda \mathrm{w}^{\prime \prime} .1 \underline{\mathrm{x}}_{\langle\mathrm{s}, \mathrm{e}}\left[\operatorname{price}\left(\underline{\mathrm{x}}, \mathrm{w}^{\prime \prime}\right) \& \forall \mathrm{w}^{\prime \prime \prime} \in \operatorname{Dox}_{\mathrm{fred}}\left(\mathrm{w}^{\prime \prime}\right)\left[\underline{\mathrm{x}}\left(\mathrm{w}^{\prime \prime \prime}\right)=\underline{\mathrm{x}}\left(\mathrm{w}^{\prime \prime}\right)\right]\right](\mathrm{w})\right]
\end{aligned}
$$

c. Simplification:

$$
\begin{aligned}
& \lambda \mathrm{w} . \forall \mathrm{w}^{\prime} \in \operatorname{Dox}_{\mathrm{j}}(\mathrm{w}) \\
& {\left[\underline{\mathrm{t}}_{\langle\mathrm{s}, \mathrm{e}\rangle}\left[\operatorname{price}\left(\underline{\mathrm{x}}, \mathrm{w}^{\prime}\right) \& \forall \mathrm{w}^{\prime \prime \prime} \in \operatorname{Dox}_{\text {fred }}\left(\mathrm{w}^{\prime}\right)\left[\underline{\mathrm{x}}\left(\mathrm{w}^{\prime \prime \prime}\right)=\underline{\mathrm{x}}\left(\mathrm{w}^{\prime}\right)\right]\right]=\right.} \\
& \left.\underline{1 \underline{\mathrm{x}}_{\langle\mathrm{s}, \mathrm{e}\rangle}}\left[\operatorname{price}(\underline{\mathrm{x}}, \mathrm{w}) \& \forall \mathrm{w}^{\prime \prime \prime} \in \operatorname{Dox}_{\text {fred }}(\mathrm{w})\left[\underline{\mathrm{x}}\left(\mathrm{w}^{\prime \prime \prime}\right)=\underline{\mathrm{x}}(\mathrm{w})\right]\right]\right]
\end{aligned}
$$

The resulting truth-conditions in (34c) roughly state the following: we are in a world $w$ such that, in all of John's doxastic alternatives $w^{\prime}$ in $w$, the price $\underline{x}_{\langle\mathrm{s}, \mathrm{e}}$ that Fred knows in $\mathrm{w}^{\prime}$ is exactly the price $\underline{\mathrm{x}}_{\langle\mathrm{s}, \mathrm{e}}>$ that Fred knows in the actual world w. This correctly captures reading B.

Implementation (ii) involves separating the semantic content in (31) into two different lexical entries: a simpler lexical entry for know and an answer operator ANs. ${ }^{4}$

4. This type of division of semantic labor is proposed in the literature for know plus interrogative clauses (Heim (1994), Beck-Rullmann (1999)). The insight behind it is that know, remember, guess, etc., can all have a strongly exhaustive reading, as in (i), and a mention-some reading, as illustrated in (ii). One can build the two degrees of exhaustivity into each verb (having two lexical entries for each verb, or perhaps a basic entry and a fixed algorithm to derive the second); or one

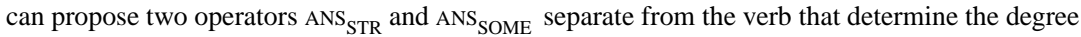
of exhaustivity in each sentence. In CQs, the same degrees or exhaustivity can be found, as illustrated in (iii)-(iv) for Catalan, and again the different degrees of exhaustivity can be built into ANS operators separate from the verb.

(i) John knows / remembers / guessed what students came.

'For all students $\mathrm{x}$ that came, John knows that $\mathrm{x}$ came, and for all students $\mathrm{x}$ that did not come, John knows that $\mathrm{x}$ did not come.'

(ii) John knows / remembers/ guessed where one can buy Spanish ham in Philadelphia.

'For some place $\mathrm{x}$ in Philadelphia, John knows that one can buy Spanish ham in x.'

(iii) Sé els nens que van venir.

I-know the kids that AUX come.

'I know the kids that came', meaning 'For all kids $\mathrm{x}$ that came, I know that $\mathrm{x}$ came, and for all the kids $\mathrm{x}$ that did not come, $\mathrm{I}$ know that $\mathrm{x}$ did not come'.

(iv) Sé / Et diré el professor que (també) et pot ajudar.

I-know / To-you I-will-tell the professor that (also) you-Acc can help

'I know / I'll tell you the professor that (also) can help you', meaning 'For some professor $\mathrm{x}$ that can help you, I know / I'll tell you that x (also) can help you'. 
On the one hand, the content of know is remodeled as in (35). On the other, a (strongly exhaustive) answer operator ANs is defined in (36), where $\unrhd$ is a variable of type $\langle\mathrm{s}, \mathrm{e}\rangle$ or $\langle\mathrm{s},\langle\mathrm{s}, \mathrm{e}\rangle>$ :

(35) $[[k n o w]]=\lambda \mathrm{p}_{\langle\mathrm{s},<\mathrm{s}, \mathrm{t}\rangle} \lambda \mathrm{x}_{\mathrm{e}} \lambda \mathrm{w} . \forall \mathrm{w}^{\prime} \in \operatorname{Dox}_{\mathrm{x}}(\mathrm{w})\left[\mathrm{p}(\mathrm{w})\left(\mathrm{w}^{\prime}\right)=1\right]$

(36) ANS (y) $=\lambda w \lambda w^{\prime} \cdot y\left(w^{\prime}\right)=y(w)$

The ambiguity between reading $\mathrm{A}$ and reading $\mathrm{B}$ obtains as follows. In reading A, ANS applies to the extension of the NP in the evaluation world $\mathrm{w}$, and $\operatorname{ANS}\left(\left[\left[_{N P}\right]\right]^{\mathrm{g}}(\mathrm{w})\right)$ is then fed as the argument of know:

(37) John knows the price that Fred knows.

(38) Reading A:

a. Extension of NP in w:

$$
\underline{\mathrm{t}}_{<\mathrm{s}, \mathrm{e}\rangle}\left[\operatorname{price}(\underline{\mathrm{x}}, \mathrm{w}) \& \forall \mathrm{w}^{\prime \prime \prime} \in \operatorname{Dox}_{\text {fred }}(\mathrm{w})\left[\underline{\mathrm{x}}\left(\mathrm{w}^{\prime \prime \prime}\right)=\underline{\mathrm{x}}(\mathrm{w})\right]\right]
$$

b. ANS + extension of the NP: ${ }^{5}$

ANS $\left([[N P]]^{g}(w)\right)=$

$\lambda \mathrm{w}^{*} \lambda \mathrm{w}^{\prime} . \underline{\mathrm{tx}}_{\langle\mathrm{s}, \mathrm{e}\rangle}\left[\operatorname{price}(\underline{\mathrm{x}}, \mathrm{w}) \& \forall \mathrm{w}^{\prime \prime \prime} \in \operatorname{Dox}_{\mathrm{fred}}(\mathrm{w})\left[\underline{\mathrm{x}}\left(\mathrm{w}^{\prime \prime \prime}\right)=\underline{\mathrm{x}}(\mathrm{w})\right]\right]\left(\mathrm{w}^{\prime}\right)=$

$\underline{\underline{x}}_{\langle\mathrm{s}, \mathrm{e}\rangle}\left[\operatorname{price}(\underline{\mathrm{x}}, \mathrm{w}) \& \forall \mathrm{w}^{\prime \prime \prime} \in \operatorname{Dox}_{\mathrm{fred}}(\mathrm{w})\left[\underline{\mathrm{x}}\left(\mathrm{w}^{\prime \prime \prime}\right)=\underline{\mathrm{x}}(\mathrm{w})\right]\right]\left(\mathrm{w}^{*}\right)$

c. Know + ANS $\left([[\mathrm{NP}]]^{\mathrm{g}}(\mathrm{w})\right)$ :

$\lambda$ w. $\forall \mathrm{w}^{\prime} \in \operatorname{Dox}_{\mathrm{j}}(\mathrm{w})$

$\left[\underline{\mathrm{x}}_{\langle\mathrm{s}, \mathrm{e}\rangle}\left[\operatorname{price}(\underline{\mathrm{x}}, \mathrm{w}) \& \forall \mathrm{w}^{\prime \prime \prime} \in \operatorname{Dox}_{\text {fred }}(\mathrm{w})\left[\underline{\mathrm{x}}\left(\mathrm{w}^{\prime \prime \prime}\right)=\underline{\mathrm{x}}(\mathrm{w})\right]\right]\left(\mathrm{w}^{\prime}\right)=\right.$ $\left.\underline{\mathrm{t}}_{\langle\mathrm{x}, \mathrm{e}\rangle}\left[\operatorname{price}(\underline{\mathrm{x}}, \mathrm{w}) \& \forall \mathrm{w}^{\prime \prime \prime} \in \operatorname{Dox}_{\mathrm{fred}}(\mathrm{w})\left[\underline{\mathrm{x}}\left(\mathrm{w}^{\prime \prime \prime}\right)=\underline{\mathrm{x}}(\mathrm{w})\right]\right] \quad(\mathrm{w}) \quad\right]$

In reading $\mathrm{B}$, ANS applies to the intension of the NP, and ANS([[NP] $\left.]^{\mathrm{g}}\right)$ is the argument of know:

(39) Reading B:

a. Intension of the NP:

$$
\lambda \mathrm{w}^{\prime \prime} . \underline{\mathrm{x}}_{\langle\mathrm{s}, \mathrm{e}>}\left[\operatorname{price}\left(\underline{\mathrm{x}}, \mathrm{w}^{\prime \prime}\right) \& \forall \mathrm{w}^{\prime \prime \prime} \in \operatorname{Dox}_{\text {fred }}\left(\mathrm{w}^{\prime \prime}\right)\left[\underline{\mathrm{x}}\left(\mathrm{w}^{\prime \prime \prime}\right)=\underline{\mathrm{x}}\left(\mathrm{w}^{\prime \prime}\right)\right]\right]
$$

b. ANS + intension of the NP:

ANS $\left([[\mathrm{NP}]]^{\mathrm{g}}\right)=$

$\lambda w \lambda w^{\prime} .\left[\lambda w^{\prime \prime} .1 \underline{x}_{\langle s, e\rangle}\left[\operatorname{price}\left(\underline{x}, w^{\prime \prime}\right) \& \forall w^{\prime \prime \prime} \in \operatorname{Dox}_{f r e d}\left(w^{\prime \prime}\right)\left[\underline{x}\left(w^{\prime \prime \prime}\right)=\right.\right.\right.$ $\left.\left.\left.\underline{\mathrm{x}}\left(\mathrm{w}^{\prime \prime}\right)\right]\right]\right]\left(\mathrm{w}^{\prime}\right)=$

$\left[\lambda \mathrm{w}^{\prime \prime} . \underline{\mathrm{x}}_{\langle\mathrm{s}, \mathrm{e}>}\left[\operatorname{price}\left(\underline{\mathrm{x}}, \mathrm{w}^{\prime \prime}\right) \& \forall \mathrm{w}^{\prime \prime \prime} \in \operatorname{Dox}_{\mathrm{fred}}\left(\mathrm{w}^{\prime \prime}\right)\left[\underline{\mathrm{x}}\left(\mathrm{w}^{\prime \prime \prime}\right)=\right.\right.\right.$ $\left.\left.\left.\underline{\mathrm{x}}\left(\mathrm{w}^{\prime \prime}\right)\right]\right]\right](\mathrm{w})$

5. In (38b), I use the alphabetical variant (i) of the ANS operator (36) in order to avoid accidental binding of the free variable $w$ in (38a). For the combination of (38b) with matrix [[know]] to yield (38c), see footnote 3 .

(i) ANS (y) $=\lambda \mathrm{w}^{*} \lambda \mathrm{w}^{\prime} \cdot \mathrm{y}\left(\mathrm{w}^{\prime}\right)=\mathrm{y}\left(\mathrm{w}^{*}\right)$ 
c. Simplification:

$$
\begin{aligned}
& \lambda w \lambda w^{\prime} .1 \underline{x}_{<s, e>}\left[\operatorname{price}\left(\underline{x}, w^{\prime}\right) \& \forall w^{\prime \prime \prime} \in \operatorname{Dox}_{\text {fred }}\left(w^{\prime}\right)\left[\underline{x}\left(w^{\prime \prime \prime}\right)=\underline{x}\left(w^{\prime}\right)\right]\right]=
\end{aligned}
$$

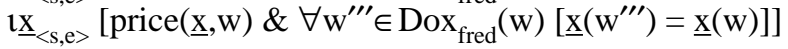

d. Know + ANS $\left([[\mathrm{NP}]]^{\mathrm{g}}\right)$ :

$$
\begin{aligned}
& \lambda w . \forall w^{\prime} \in \operatorname{Dox}_{j}(w) \\
& {\left[\quad \underline{x}_{\langle\mathrm{s}, \mathrm{e}>}\left[\operatorname{price}\left(\underline{\mathrm{x}}, \mathrm{w}^{\prime}\right) \& \forall \mathrm{w}^{\prime \prime \prime} \in \operatorname{Dox}_{\text {fred }}\left(\mathrm{w}^{\prime}\right)\left[\underline{\mathrm{x}}\left(\mathrm{w}^{\prime \prime \prime}\right)=\underline{\mathrm{x}}\left(\mathrm{w}^{\prime}\right)\right]\right]=\right.} \\
& \left.\underline{\mathrm{tx}}_{\langle\mathrm{s}, \mathrm{e}>}\left[\operatorname{price}(\underline{\mathrm{x}}, \mathrm{w}) \& \forall \mathrm{w}^{\prime \prime \prime} \in \operatorname{Dox}_{\text {fred }}(\mathrm{w})\left[\underline{\mathrm{x}}\left(\mathrm{w}^{\prime \prime \prime}\right)=\underline{\mathrm{x}}(\mathrm{w})\right]\right]\right]
\end{aligned}
$$

Both implementations lead to the exact same formulae, i.e., to the same final truth conditions for reading A on the one hand and reading B on the other. The only difference involves what the argument of know is: the NP itself, as represented in (28), or a complex phrase containing ANS and the NP, as in (29).

In sum, we have seen that the ambiguity between reading A and reading $\mathrm{B}$ follows from the intensionality of know. Like other intensional verbs needing an intensional object as their argument, know can derive this intensional object from the extension (reading A) or from the intension of the NP (reading B). In implementation (i), this intensional object directly corresponds to the extension/intension of the NP. In implementation (ii), this intensional object is the result of applying ANS to the extension/intension of the NP.

\subsection{The ambiguity in SSs}

We have seen that the ambiguity observed for CQs stems from the intensionality of know. This predicts that no such ambiguity should arise when we have the same nested NP structure with purely extensional verbs, like touch or be cheap/expensive. This prediction is borne out, as shown in (40)-(41).

(40) John touched the price that Fred touched.

(41) The price that they thought was cheap was (actually) expensive.

Crucially, SSs with specificational be display readings parallel to reading A and reading B of CQs with know. In the same way that a given concealed question $\mathrm{NP}$ can contribute a question or a meta-question, so can a given specificational subject NP -e.g. $I_{N P}$ the price that Fred thought was $\left.\$ 1.29\right]$ - ambiguously contribute a question or a meta-question. After the copula, the answer to that question or meta-question is enunciated, and this naturally disambiguates the reading. The example and paraphrase in (42)-(43) illustrate reading A and (44)-(45) exemplify reading $\mathrm{B}$ :

(42) The price that Fred thought was $\$ 1.29$ was (actually) $\$ 1.79$. 
(43) Reading A: 'The question whose answer Fred thought was ' $\$ 1.29$ ' has as its real answer ' $\$ 1.79$ '.'

There are several relevant questions about prices: «How much is the milk?» «How much is the oil?» «How much is the ham?» For one of these questions -e.g., the first one-, Fred thought the answer was '\$1.29'.

But the actual answer to this question is ' $\$ 1.79$ '.

(44) The price that Fred thought was $\$ 1.29$ was the price of milk.

(45) Reading B: 'The question whose answer Fred thought was ' $\$ 1.29$ ' is 'How much is the milk?'.'

There are several relevant questions about prices: «How much is the milk?» «How much is the oil?» «How much is the ham?»

For one of these questions, Fred thought the answer was ' $\$ 1.29$ '.

Then, there is the «meta-question» asking which of these questions is the one whose answer Fred thought was \$1.29.

The answer to the meta-question is «How much is the milk?».

That is, Fred thought that the price of milk was $\$ 1.29$.

The possibility of having reading A and reading B in SSs is attested in other languages, like Catalan (in (46)-(47)) and German ((48)-(49)): ${ }^{6}$

(46) El regal que pensàvem que seria un cotxe va ser una The present that we-thought that would-be a car AUX be a carbassa. pumpkin

'The present that we thought would be a car was a pumpkin.'

6. To ensure that copular sentences with the A/B ambiguity are specificational, Romero (2003) provides the following examples with variable binding connectivity:

(i) Scenario for (ii)-(iii):

A group of 2-year old girls from the Ukraine was given in adoption to several families in Barcelona. The director of the adoption program encouraged the biological relatives of each girl to keep in touch with her by writing letters, telling them though that they should not identify themselves using their name, family relationship or address. After a couple of years, the girls have developed some hypotheses about who every secret writer may or may not be. For example, no girl thinks that the one who writes to her the least can possibly be her mother. In fact, they are all right about that, since, for every girl, the one who writes to her the least is her uncle.

(ii) The anonymous writer that no girl ${ }_{1}$ thinks can possibly be her ${ }_{1}$ mother is (in fact) her ${ }_{1}$ uncle. READING A

(iii) The anonymous writer that no girl ${ }_{1}$ thinks can possibly be her ${ }_{1}$ mother is the one who writes to her ${ }_{1}$ the least.

READING B 
(47) El regal que pensàvem que seria un cotxe era el que The present that we-thought that would-be a car was the that va portar la Bombi.

AUX bring the Bombi

'The present that we thought would be a car was the one that Bombi brought.'

(48) Der Preis, von dem Hans glaubte, dass er $\$ 1.29$ war, war in The-masc price of which Hans believed that he $\$ 1.29$ was was in Wirklichkeit $\$ 1.79$. reality $\$ 1.79$

'The price that Hans thought was $\$ 1.29$ was in reality $\$ 1.79$.'

(49) Der Preis, von dem Hans glaubte, dass er $\$ 1.29$ war, war The-masc price of which Hans believed that he $\$ 1.29$ was was der Milchpreis. the milk-price

'The price that Hans thought was $\$ 1.29$ was the price of milk.'

Given that the ambiguity found in CQs is exactly parallel to the readings found in SSs, a unified account of the ambiguity is desirable. In the same way that know is an intensional verb taking an intensional object as its semantic argument, specificational be is an intensional verb taking an intensional object as its (subject) semantic argument. As with know, reading A obtains when this intensional object arises from the extension of the SS and reading B obtains when it arises from the intension of the SS, as sketched in (50):

(50) The price that Fred thought was $\$ 1.29$ was ...

a. Reading A: EXTENSION of $\left[_{N P}\right.$ the price that Fred thought was \$1.29] + [[be ....]

b. Reading B: INTENSION of $\int_{N P}$ the price that Fred thought was \$1.29] + [[be ....]

Again, this idea can be pursued through implementation (i) or through implementation (ii). In either case, the semantic computation of the SS is as spelled out in $(51):^{7}$

7. For simplicity, the semantic value of the embedded CP $\left[{ }_{C P} t_{5}\right.$ was $\left.\$ 1.29\right]$ is spelled out as $\lambda \mathrm{w}$. $\mathrm{g}(5)(\mathrm{w})=\$ 1.29$ for both implementations. The differences between the two implementations will be illustrated only for matrix $b e$. 
(51) [[the price that Fred thought was \$1.29] $]^{\mathrm{g}} \quad=$

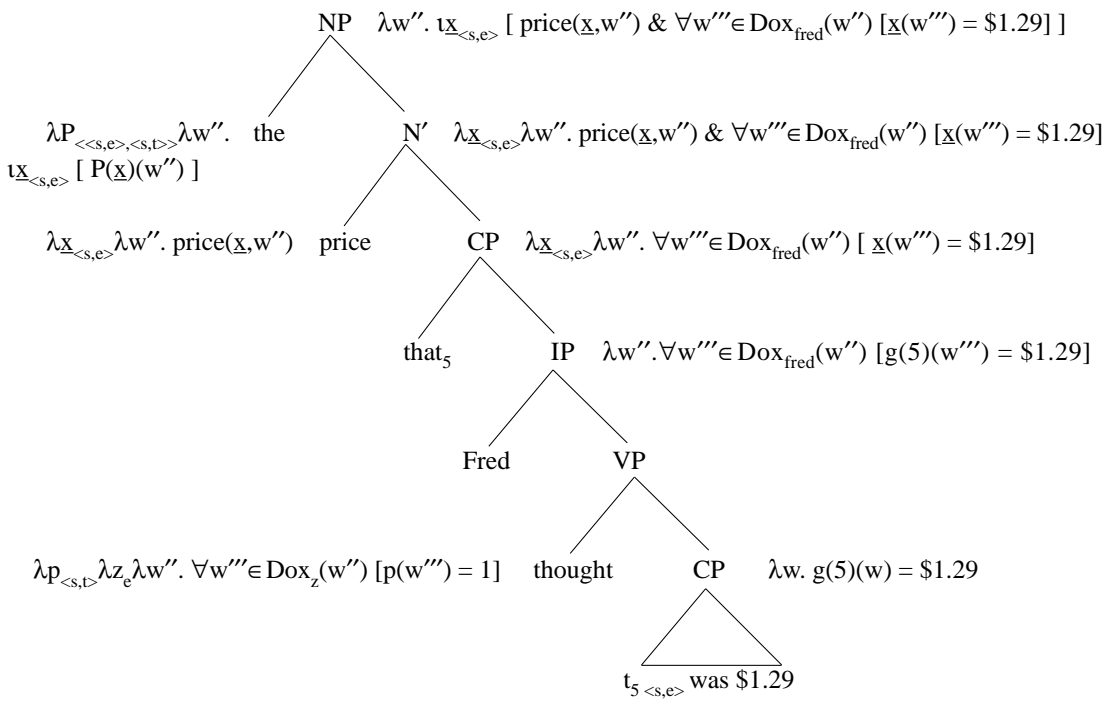

In implementation (i), specificational be has the meaning in (52), where y may be of type $\langle\mathrm{s}, \mathrm{e}\rangle$ and $\langle\mathrm{s},\langle\mathrm{s}, \mathrm{e}\rangle>$, and $\mathrm{z}$-with one degree less of intensionalitymay have the type e or $\langle\mathrm{s}, \mathrm{e}\rangle$. The semantic contribution of the SS combines directly with [[I']], as made explicit in the syntactic representation (53). Note, further, than the post-verbal constituent is an NP (as in Jacobson (1994), Sharvit (1999), Cecchetto (2000), Heller (2002)). When the SS contributes its extension, reading A arises, as shown in (54). When the SS contributes its intension, we obtain reading B, as indicated in (55).

$$
[[b e]]=\lambda z \lambda \underline{y} \lambda \mathrm{w}_{\mathrm{s}} \cdot \mathrm{y}(\mathrm{w})=\mathrm{z}
$$

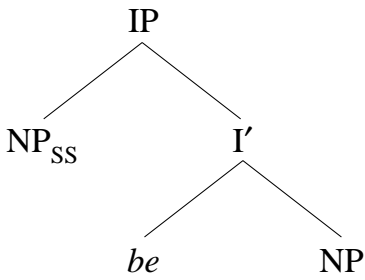

(54) Reading A:

a. Extension of NP in w:

$$
\underline{\mathrm{t}}_{\langle\mathrm{s}, \mathrm{e}\rangle}\left[\operatorname{price}(\underline{\mathrm{x}}, \mathrm{w}) \& \forall \mathrm{w}^{\prime \prime \prime} \in \operatorname{Dox}_{\text {fred }}(\mathrm{w})\left[\underline{\mathrm{x}}\left(\mathrm{w}^{\prime \prime \prime}\right)=\$ 1.29\right]\right]
$$

b. Extension of the NP $+[[b e \ldots]]$

$\lambda \mathrm{w} .\left[\underline{\mathrm{x}}_{\langle\mathrm{s}, \mathrm{e}\rangle}\left[\mathrm{price}(\underline{\mathrm{x}}, \mathrm{w}) \& \forall \mathrm{w}^{\prime \prime \prime} \in \operatorname{Dox}_{\text {fred }}(\mathrm{w})\left[\underline{\mathrm{x}}\left(\mathrm{w}^{\prime \prime \prime}\right)=\$ 1.29\right]\right](\mathrm{w})=\$ 1.79\right]$ 


\section{(55) Reading B:}

a. Intension of NP:

$$
\lambda \mathrm{w}^{\prime \prime} .1 \underline{\mathrm{x}}_{\langle\mathrm{s}, \mathrm{e}>}\left[\operatorname{price}\left(\underline{\mathrm{x}}, \mathrm{w}^{\prime \prime}\right) \& \forall \mathrm{w}^{\prime \prime \prime} \in \operatorname{Dox}_{\text {fred }}\left(\mathrm{w}^{\prime \prime}\right)\left[\underline{\mathrm{x}}\left(\mathrm{w}^{\prime \prime \prime}\right)=\$ 1.29\right]\right]
$$

b. Intension of the NP $+[[b e \ldots]]$

$\lambda \mathrm{w} .\left[\lambda \mathrm{w}^{\prime \prime} . \underline{\mathrm{x}}_{<\mathrm{s}, \mathrm{e}>}\left[\operatorname{price}\left(\underline{\mathrm{x}}, \mathrm{w}^{\prime \prime}\right) \& \forall \mathrm{w}^{\prime \prime \prime} \in \operatorname{Dox}_{\text {fred }}\left(\mathrm{w}^{\prime \prime}\right)\left[\underline{\mathrm{x}}\left(\mathrm{w}^{\prime \prime \prime}\right)=\right.\right.\right.$ $\$ 1.29]$ ] $\left.\left.(\mathrm{w})=\underline{t x}_{\langle\mathrm{s}, \mathrm{e}}\right\rangle[\operatorname{price}-\mathrm{of}-\operatorname{milk}(\underline{\mathrm{x}}, \mathrm{w})]\right]$

c. Simplification:

$$
\begin{aligned}
& \lambda \mathrm{w} \text {. [ } \underline{\mathrm{x}}_{\langle\mathrm{s}, \mathrm{e}\rangle}\left[\operatorname{price}(\underline{\mathrm{x}}, \mathrm{w}) \& \forall \mathrm{w}^{\prime \prime \prime} \in \operatorname{Dox}_{\mathrm{fred}}(\mathrm{w})\left[\underline{\mathrm{x}}\left(\mathrm{w}^{\prime \prime \prime}\right)=\$ 1.29\right]\right]= \\
& \left.\underline{\underline{x}}_{\langle\mathrm{s}, \mathrm{e}>}[\text { price-of-milk }(\underline{\mathrm{x}}, \mathrm{w})]\right]
\end{aligned}
$$

We turn now to implementation (ii) ${ }^{8}$ Here the complex ANS([[SS] $\left.]^{\mathrm{g}}\right)$ is the argument of be, as shown in (56). ANs is the same answer operator that we used with CQs in (36), repeated here as (57), where y can have type $\langle\mathrm{s}, \mathrm{e}\rangle$ or $\langle\mathrm{s},\langle\mathrm{s}, \mathrm{e}\rangle\rangle$. This means that the pre-verbal semantic argument of $b e$ must be a propositional concept (type $\langle\mathrm{s},\langle\mathrm{s}, \mathrm{t}\rangle\rangle$ ), and that the post-verbal semantic argument must correspondingly be a proposition (type $<\mathrm{s}, \mathrm{t}>$ ), as specified in the lexical entry in (58).

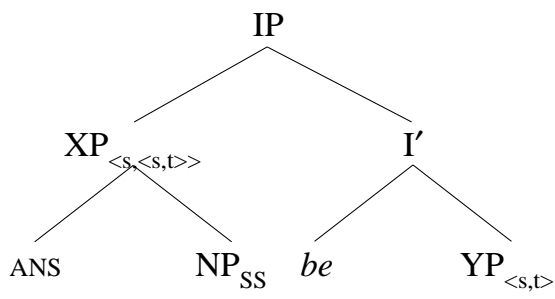

(57) $\operatorname{ANS}(\mathrm{y})=\lambda w \lambda w^{\prime} \cdot \underline{y}\left(w^{\prime}\right)=\underline{y}(w)$

(58) $[[b e]]=\lambda \mathrm{q}_{\langle\mathrm{s}, \mathrm{t}\rangle} \lambda \mathrm{p}_{\langle\mathrm{s},\langle\mathrm{s}, \mathrm{t}\rangle>} \lambda \mathrm{w} \cdot \mathrm{p}(\mathrm{w})=\mathrm{q}$

8. The same flexibility in degrees of exhaustivity observed in footnote 4 for full interrogative clauses and for CQs is present in SSs, witness the Catalan examples (i)-(ii). Example (i) is more naturally read as giving the (strongly) exhaustive list of the kids that came. Example (ii) has a mentionsome reading according the which the speaker is suggesting a particular professor as a possible source of help, without committing herself to whether or not this is the only professor that may provide help. Again, this flexibility brings up the possibility of severing the degree of exhaustivity from the verb $b e$ and treating it as a separate ANS operator, as done in implementation (ii).

(i) Els nens que van venir van ser el Pere, la Núria i la Raquel.

The kids that AUX come AUX be the Pere, the Núria and the Raquel.

'The kids that came were Pere, Núria i Raquel.'

(ii) El professor que (també) et pot ajudar és el Quetglas.

The professor that (also) to-you can help is the Quetglas.

'The professor that (also) can help you is Quetglas.' 
This semantic picture is matched by a syntactic analysis in which the postcopular constituent is not a simple NP but rather a clause that has undergone partial deletion, as suggested in Ross (1972), den Dikken et al. (2000), Ross (2000) and Schlenker (2003). Under this analysis, an example like (59a) has the underlying structure in (59b), and example (60a) has the structure in (60b), where the postcopular $\left[_{Y P} \$ 1.79\right]$ can be understood as a verbless clause (see Schlenker 2003), comparable to a Small Clause:

(59) a. What he ate was potatoes.

b. What he ate was $[$ IP potatoes]

(60) a. The price of milk is $\$ 1.79$.

b. The price of milk is [YP \$1.79]

We now apply this syntactic and semantic analysis to the examples of reading A and reading B at issue. Reading A has the underlying structure in (61), where the deleted predicate $P$ in the post-copular constituent stands for the (predicational) property of being the actual value of the price $\left.\underline{x}_{\langle\mathrm{s}, \mathrm{e}}\right\rangle$ that Fred thinks is $\$ 1.29$. (62) sketches the semantic computation: ${ }^{9}$

(61) The price that Fred thought was $\$ 1.29$ is $\mathbf{P} \$ 1.79$.

(62) Reading A:

a. Extension of NP in w:

$$
\underline{\mathrm{tx}}_{<\mathrm{s}, \mathrm{e}\rangle}\left[\operatorname{price}(\underline{\mathrm{x}}, \mathrm{w}) \& \forall \mathrm{w}^{\prime \prime \prime} \in \operatorname{Dox}_{\text {fred }}(\mathrm{w})\left[\underline{\mathrm{x}}\left(\mathrm{w}^{\prime \prime \prime}\right)=\$ 1.29\right]\right]
$$

b. ANS + extension of the NP: ${ }^{10}$

ANS $\left([[\mathrm{NP}]]^{\mathrm{g}}(\mathrm{w})\right)=$

$\lambda \mathrm{w}^{*} \lambda \mathrm{w}^{\prime} . \underline{\mathrm{x}}_{\langle\mathrm{s}, \mathrm{e}\rangle}\left[\operatorname{price}(\underline{\mathrm{x}}, \mathrm{w}) \& \forall \mathrm{w}^{\prime \prime \prime} \in \operatorname{Dox}_{\text {fred }}(\mathrm{w})\left[\underline{\mathrm{x}}\left(\mathrm{w}^{\prime \prime \prime}\right)=\$ 1.29\right]\right]\left(\mathrm{w}^{\prime}\right)=$ $\underline{1}_{\underline{\mathrm{x}}, \mathrm{e}\rangle}\left[\operatorname{price}(\underline{\mathrm{x}}, \mathrm{w}) \& \forall \mathrm{w}^{\prime \prime \prime} \in \operatorname{Dox}_{\mathrm{fred}}(\mathrm{w})\left[\underline{\mathrm{x}}\left(\mathrm{w}^{\prime \prime \prime}\right)=\$ 1.29\right]\right]\left(\mathrm{w}^{*}\right)$

c. ANS $\left([[\mathrm{NP}]]^{\mathrm{g}}(\mathrm{w})\right)+\left[\left[b^{2}\right.\right.$... ]]:

$\lambda \mathrm{w}\left[\lambda \mathrm{w}^{\prime}\left[\underline{\mathrm{x}}_{\langle\mathrm{s}, \mathrm{e}\rangle}\left[\operatorname{price}(\underline{\mathrm{x}}, \mathrm{w}) \& \forall \mathrm{w}^{\prime \prime \prime} \in \operatorname{Dox}_{\text {fred }}(\mathrm{w})\left[\underline{\mathrm{x}}\left(\mathrm{w}^{\prime \prime \prime}\right)=\$ 1.29\right]\right]\left(\mathrm{w}^{\prime}\right)=\right.\right.$ $\underline{\underline{x}}_{\langle s, e>}\left[\operatorname{price}(\underline{\mathrm{x}}, \mathrm{w}) \& \forall \mathrm{w}^{\prime \prime \prime} \in \operatorname{Dox}_{\text {fred }}(\mathrm{w})\left[\underline{\mathrm{x}}\left(\mathrm{w}^{\prime \prime \prime}\right)=\$ 1.29\right]\right]$ (w) ] $\left.=\lambda \mathrm{w}^{\prime} \cdot \mathrm{P}\left(\$ 1.79, \mathrm{w}^{\prime}\right)\right]$

The final proposition in (62c) can be roughly paraphrased as in (63). This proposition correctly captures the truth conditions of reading A:

9. The expression $\lambda w^{\prime} . P\left(\$ 1.79, w^{\prime}\right)$ in $(62 c)$ is used to reflect the predication within the verbless clause $\left[_{Y P} \neq \$ 1.79\right]$.

10. See footnote 5 for the step (62b), and apply the content of footnote 3 to matrix be for the step $(62 c)$. 
(63) Paraphrase of (62c):

'We are in a world $\mathrm{w}$ such that: the unique price $\underline{\mathrm{x}}_{\langle\mathrm{s}, \mathrm{e}\rangle}$ in $\mathrm{w}$ that Fred thinks has the value $\$ 1.29$, and the actual value $\mathrm{x}_{\mathrm{e}}$ of $\left.\underline{\mathrm{x}}_{\langle\mathrm{s}, \mathrm{e}}\right\rangle$ in $\mathrm{w}$ are such that: the proposition «the value of $\underline{\mathrm{x}}_{\langle\mathrm{s}, \mathrm{e}\rangle}$ equals $\mathrm{x}_{\mathrm{e}}$ » is the same as the proposition «\$1.79 has the property of being the value of $\left.\mathrm{x}_{\langle\mathrm{s}, \mathrm{e}\rangle}\right\rangle$.'

Reading B is represented and computed in (64)-(65):

(64) The price that Fred thought was $\$ 1.29$ was the price of milk $\$ 1.29$.

(65) Reading B:

a. Intension of NP:

$$
\lambda \mathrm{w}^{\prime \prime} . \underline{\mathrm{x}}_{\langle\mathrm{s}, \mathrm{e}>}\left[\operatorname{price}\left(\underline{\mathrm{x}}, \mathrm{w}^{\prime \prime}\right) \& \forall \mathrm{w}^{\prime \prime \prime} \in \operatorname{Dox}_{\text {fred }}\left(\mathrm{w}^{\prime \prime}\right)\left[\underline{\mathrm{x}}\left(\mathrm{w}^{\prime \prime \prime}\right)=\$ 1.29\right]\right]
$$

b. ANS + intension of the NP:

$\operatorname{ANS}\left([[\mathrm{NP}]]^{\mathrm{g}}\right)=$

$$
\lambda w \lambda w^{\prime} .\left[\lambda w ^ { \prime \prime } \cdot \underline { x } _ { \langle \mathrm { s } , \mathrm { e } } \left[\operatorname { p r i c e } ( \underline { \mathrm { x } } , \mathrm { w } ^ { \prime \prime } ) \& \forall \mathrm { w } ^ { \prime \prime \prime } \in \operatorname { D o x } _ { \text { fred } } ( \mathrm { w } ^ { \prime \prime } ) \left[\underline{\mathrm{x}}\left(\mathrm{w}^{\prime \prime \prime}\right)=\right.\right.\right.
$$
$\$ 1.29]]]\left(\mathrm{w}^{\prime}\right)=$

$\left[\lambda \mathrm{w}^{\prime \prime} . \underline{\mathrm{x}}_{\langle\mathrm{s}, \mathrm{e}\rangle}\left[\operatorname{price}\left(\underline{\mathrm{x}}, \mathrm{w}^{\prime \prime}\right) \& \forall \mathrm{w}^{\prime \prime \prime} \in \operatorname{Dox}_{\mathrm{fred}}\left(\mathrm{w}^{\prime \prime}\right)\left[\underline{\mathrm{x}}\left(\mathrm{w}^{\prime \prime \prime}\right)=\right.\right.\right.$ $\$ 1.29]]](\mathrm{w})$

c. Simplification:

$$
\begin{gathered}
\lambda w \lambda \mathrm{w}^{\prime} . \underline{\mathrm{x}}_{\langle\mathrm{x}, \mathrm{e}}\left[\operatorname{price}\left(\underline{\mathrm{x}}, \mathrm{w}^{\prime}\right) \& \forall \mathrm{w}^{\prime \prime \prime} \in \operatorname{Dox}_{\mathrm{fred}}\left(\mathrm{w}^{\prime}\right)\left[\underline{\mathrm{x}}\left(\mathrm{w}^{\prime \prime \prime}\right)=\$ 1.29\right]\right]= \\
\underline{\imath \underline{\mathrm{x}}}_{\langle\mathrm{s}, \mathrm{e}\rangle}\left[\operatorname{price}(\underline{\mathrm{x}}, \mathrm{w}) \& \forall \mathrm{w}^{\prime \prime \prime} \in \operatorname{Dox}_{\text {fred }}(\mathrm{w})\left[\underline{\mathrm{x}}\left(\mathrm{w}^{\prime \prime \prime}\right)=\$ 1.29\right]\right]
\end{gathered}
$$

d. ANS $\left([[\mathrm{NP}]]^{\mathrm{g}}\right)+[[$ be ...]]:

$\lambda \mathrm{w}\left[\lambda \mathrm{w}^{\prime}\left[\underline{\mathrm{lx}}_{<\mathrm{s}, \mathrm{e}\rangle}\left[\operatorname{price}\left(\underline{\mathrm{x}}, \mathrm{w}^{\prime}\right) \& \forall \mathrm{w}^{\prime \prime \prime} \in \operatorname{Dox}_{\text {fred }}\left(\mathrm{w}^{\prime}\right)\left[\underline{\mathrm{x}}\left(\mathrm{w}^{\prime \prime \prime}\right)=\$ 1.29\right]\right]=\right.\right.$ $\underline{\underline{x}}_{\langle\mathrm{s}, \mathrm{e}\rangle}\left[\operatorname{price}(\underline{\mathrm{x}}, \mathrm{w}) \& \forall \mathrm{w}^{\prime \prime \prime} \in \operatorname{Dox}_{\text {fred }}(\mathrm{w})\left[\underline{\mathrm{x}}\left(\mathrm{w}^{\prime \prime \prime}\right)=\$ 1.29\right]\right]$ $=\lambda \mathrm{w}^{\prime} \cdot \forall \mathrm{w}^{\prime \prime \prime} \in \operatorname{Dox}_{\text {fred }}\left(\mathrm{w}^{\prime}\right)\left[\right.$ price-of-milk $\left.\left(\mathrm{w}^{\prime \prime \prime}\right)=\$ 1.29\right]$ ]

The final proposition in (65d) is paraphrased in (66). This proposition (roughly) corresponds to the truth-conditions of reading $\mathrm{B}$ :

(66) 'We are in a world w such that: the unique price $\underline{x}_{\langle s, e\rangle}$ in w that Fred thinks has the value $\$ 1.29$ is such that the proposition «the price that Fred thinks has the value $\$ 1.29$ equals $\underline{x}_{\langle\mathrm{s}, \mathrm{e}\rangle} »$ is the same as the proposition «Fred thinks the price of milk has the value $\$ 1.29 »$. $^{11}$

11. For the proposition in (65d) to exactly represent reading B, we need to amend the presuppositional mismatch between the first embedded proposition "the price that Fred thinks has the value $\$ 1.29$ equals $\left.\underline{\mathrm{x}}_{\langle\mathrm{s}, \mathrm{e}\rangle}\right\rangle$ " -which presupposes that there is a unique price that Fred thinks has the value $\$ 1.29$ and the second embedded proposition "Fred thinks the price of milk has the value $\$ 1.29$ " -which does not carry this presupposition. Perhaps focal stress on the remnant the price of milk and the exhaustivity implicature resulting from it can be exploited to ensure this matching, along the lines suggested in Schlenker (2003). 


\subsection{Summary of section 2}

We have seen that the ambiguity that Heim (1979) detected for CQs with know also arises in SS with be, and that this ambiguity does not arise with NPs in extensional contexts. A unified intensional analysis of the two constructions has been presented following Romero (2003), and two possible implementations -(i) and (ii) - have been spelled out to cover the examples at hand. Although both implementations derive appropriate truth-conditions for readings $\mathrm{A}$ and $\mathrm{B}$, they differ in interesting ways in the manner they achieve them. Implementation (i) combines the contribution of the CQ/SS directly with the verb, and it assumes that the postcopular constituent is entirely overt (just an NP in the examples above). In implementation (ii), the answer operator ANS mediates between the CQ/SS and the verb, and the post-copular constituent is a partially elided clause.

The question then arises whether there is any empirical evidence to favor one implementation over the other. In the next section, three sets of data will be presented that further argue for a unified account of CQs and SSs and that offer support for implementation (ii). The choice of implementation has consequences for the syntax of the post-copular phrase and thus for the explanation of connectivity effects, which we will briefly discuss in the conclusions.

\section{Data in support of implementation (ii)}

\subsection{Pronominalization}

Gender marking in English is based on the referential properties of the NP. Pronouns referring to an extensional individual $\mathrm{x}_{\mathrm{e}}$ typically appear in the gender corresponding to that individual in the world: in feminine if the referent is a human female, in masculine if the referent is a human male, and in neuter form (roughly) otherwise. This is illustrated in (67), where the boldface pronoun and the NP in the preceding clause are intended as correferential:

(67) a. The girl who caused the trouble was smart. She / *he / *it didn't get caught until much later.

b. The winner of the Oscar for best actress walked in. She / *he / *it was wearing a red dress.

It has been observed that pronominalization of English SSs differs in this respect (Higgins 1976, Heycock-Kroch 1999; see also Büring 1998 for German, Mikkelsen 2003 for Danish). To refer to the semantic value of a given SS, the neuter form of the pronoun must be used, disregarding the gender that the fullfledged version of the NP is usually linked to. In other words, the semantic contribution of a SS cannot be referred to by she or he, but it must be referred to by $i t$, as illustrated in (68):

(68) The girl who caused the trouble wasn't Mary. It / *She was Jane. 
Interestingly, note that the same constraint that requires neuter pronominalization of SSs holds for CQs:

(69) John guessed the winner of the Oscar for best actress before I guessed it / *her.

This observation argues for a unified account of CQs and SSs that sets them apart from regular NPs in extensional contexts, as proposed in section 2 . Furthermore, because implementation (i) and (ii) differ in the structure and semantic value of the argument of know/be, data on pronominalization also favor one implementation over the other. We now examine the predictions of each implementation.

According to implementation (i), the concealed question NP and the specificational subject NP provide an intensional object -of type $\langle$ s, e $\rangle$ or $\langle$ s, $\langle$ s, e $\rangle\rangle-$ that combines directly with their intensional verbs, as in (70). In this respect, CQs with know and SSs with be are exactly like the argument of look for or like an intensional pronoun in regular intensional contexts. Hence, CQs/SSs and regular intensional NPs are expected to pattern together.

(70) Implementation (i):

a.

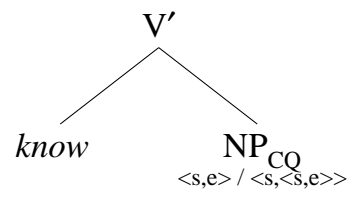

b.

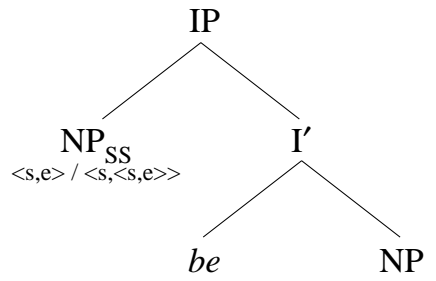

In contrast, in implementation (ii) the CQ/SS forms a new constituent with ANS, and the semantic value of this new constituent is a propositional concept (type $<\mathrm{s},\langle\mathrm{s}, \mathrm{t}>>)$ ), as indicated in (71). Under this account, the syntax-semantics of the intensional verbs know and be is more complicated than that of regular intensional verbs, as there is an extra propositional layer, provided by ANs, between those verbs and the corresponding NPs. Thus, in implementation (ii), CQs/SSs are not expected to pattern together with regular intensional NPs.

(71) Implementation (ii):

a.

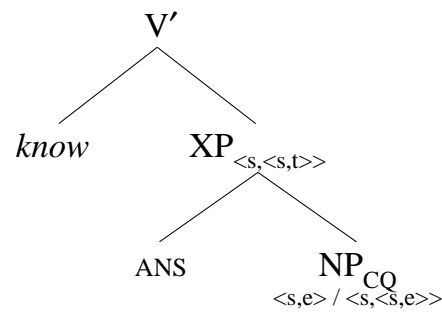

b.

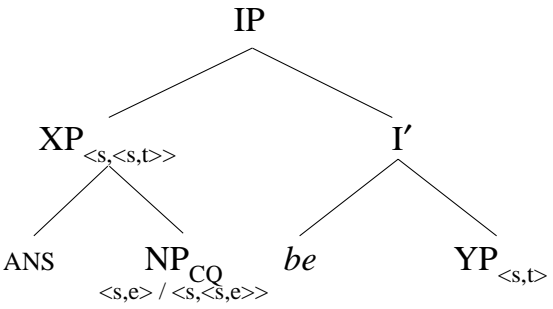


The question is thus how regular intensional NPs pronominalize. In other words, when a pronoun expresses an individual concept in intensional contexts other than question environments and specificational sentences, can it be marked for different genders? Or must it always appear in neuter form? Pronouns standing for intensional individuals in regular intensional environments are marked for gender, contrary to CQs and SSs. This is shown in (72)-(73): ${ }^{12}$

(72) Scenario: John wants to find the girl who caused the trouble, whoever that may be. The same holds for Mark.

John is looking for the girl who caused the trouble, and Mark is looking for *it / her too.

(73) Scenario: all the employees at issue are unmarried, unengaged, and have only de dicto desires about their future wives, whoever they may be.

Every employee $_{1}$ at the First Union Bank dreams of taking his ${ }_{1}$ future wife to the Bahamas, and every employee at Mellon Bank dreams of taking *it / her to Hawaii.

The contrast between CQs and SSs on the one hand and regular intensional NPs on the other is easily accounted for under implementation (ii) in the following way. Referents that are proposition-like are pronominalized invariably in the neuter form; referents that are individual-like are pronominalized with different gender markings. The argument of know and be is propositional in nature. In the same way that a proposition is referred to by a neuter pronoun, as shown in (74), the propositional concepts ANS([[CQ]]) and ANS([[SS]]) must be referred to by neuter $i t$. In the same way that an individual must be referred to with the appropriate gender pronoun, as we saw in (67), the corresponding individual concept must be referred to with the same gender pronoun, as (72)-(73) showed.

(74) Rosa heard [that Ramon was coming] from her father. Valen heard it from her mother.

Implementation (i), instead, leaves the contrast between CQs/SSs and regular intensional NPs completely unexplained. In all cases, the pronoun stands for an intensionalized individual. It is not clear why this intensionalized individual should be referred to by it in CQ and SS environments but by a she(/he) in other intensional contexts.

The observed pronominalization pattern is not an accident of English. It also obtains in other languages, like Finnish, where gender marking is referentially based. Finnish distinguishes only between human (hän 'he/she') and non-human (se

12. That pronouns standing for (regular) individual concepts are marked for gender is also noted in Heycock-Kroch (2002), who provide the following example:

(i) In the early days of the church the pope was very poor, but in the 18th and 19th centuries he/*it was typically very rich indeed. 
'it'). (75) provides an example of pronominalization in an extensional context with the human form of the pronoun, hän 'he/she'. The example (76) shows that a SS must be pronominalized with the non-human se 'it'. Example (77) shows that the meaning of a CQ is also referred back to with the non-human form. Example (78) shows that, when the pronoun stands for an individual concept over human individuals in a regular intensional environment, the human form hänet 'she/he-ACC' must be used.

(75) Naispääosa-Oscarin voittaja astui sisään. Female-lead-Oscar-GEN winner-NOM stepped/walked in.

Hän oli pukeutunut punaiseen pukuun.

She/he-NOM was dressed red-ILLATIVE evening-dress-ILLATIVE

'The winner of the Oscar for best actress walked in. She was wearing a red dress.'

(76) Tyttö joka aiheutti tämän ongelman ei ollut Mari.

Girl-NOM who caused this-ACC problem neg was Mari-NOM.

Se / \# hän oli Liisa.

It-NOM / \# she/he was Liisa-NOM

'The girl who caused this problem was not Mari. It / \#she was Liisa.' ${ }^{13}$

(77) Jussi arvasi naispääosa-Oscarin voittajan ennen kuin Jussi-NOM guessed female-lead-Oscar-GEN winner-ACC before(2words) Maria arvasi sen.

Maria-NOM guessed it-ACC

'Jussi guessed the winner of the best lead actress Oscar before Maria guessed it.'

(78) Jokainen työntekijä First Union Bankissa haveilee

Every-NOM worker-NOM First Union Bank-INESSIVE dreams-of vievänsä tulevan vaimonsa Bahamasaarille ja taking coming-ACC wife-ACC Baham-islands-ALLATIVE and jokainen työntekijä Mellon Bankissa haaveilee vievänsä every-NOM worker-NOM Mellon Bank-INESSIVE dreams-of taking hänet Havaijille. she/he-ACC Hawaii-ALL

'Every employee at the First Union Bank dreams of taking his future wife to the Bahamas, and every employee at Mellon Bank dreams of taking her to Hawaii.'

13. From my informant's judgements, it seems that hän 'she' can be used in some variants of (76) in which the speaker wants to refer to the actual person who caused the trouble. In (76) itself, though, hän 'she' is very awkward and se 'it' must be used, as in English. 
In conclusion, data from languages with a referentially based gender system have shown that CQs and SSs pattern together with respect to pronominalization, differing both from extensional NPs and from intensional NPs in regular intensional contexts. ${ }^{14}$ Hence, this empirical pattern argues for a unified account of CQs and SSs that sets them apart semantically from any other type of NP. This is achieved by implementation (ii), but not by implementation (i). ${ }^{15}$

14. In languages where gender is merely grammatically based, pronouns take whichever grammatical gender the corresponding NP has, regardless of its referential properties, as illustrated in (i) for German. This means that no difference is expected between extensional and regular intensional NPs on the one hand and SSs and CQs on the other. In effect, German makes no difference in the pronominalization of extensional NPs, regular intensional NPs and CQs, all of which take the grammatical gender of the corresponding NP, as (i)-(iii) show. However, as noted in Büring (1998), a specificational sentence of the form [Pronoun $+b e+$ name] in German can only have the neuter form of the pronoun in subject position, as illustrated in (iv). Büring argues that $e s$ 'it' in this sentence does not stand for the preceding SS, but that this clause is a reduced cleft (cf. "It was Jane that caused the trouble.'). I leave a more in-depth examination of this issue for future research.

(i) I habe meine Tasche verloren. Hast du sie gesehen?

I have my-FEM bag-FEM lost. Have you her-FEM seen?

'I lost my bag. Have you seen it?'

(ii) Jeder Mitarbeiter von Microsoft träumt davon, seine zukünftige Frau auf die Each worker from Microsoft dreams that-of his future wife to the Bahamas mizunehmen, und jeder Angestellte von TRADOS träumt davon, sie Bahamas to-take and each employee from TRADOS dreams that-of her nach Hawaii mitzunehmen.

to Hawaii to-take

'Each worker from Microsoft dreams of taking his future wife to the Bahamas, and each employee from TRADOS dreams of taking her to Hawaii.'

(iii) Tobi hat die Gewinnerin erraten, bevor Jens sie erraten hat.

Tobi has the-fem winner-FEM guessed before Jens her-FEM guessed has

'Tobi guessed the winner-FEM before Jens guessed it(FEM).'

(iv) Die, die Ärger gemacht hat, war nicht Claudi, es / *sie war Simone.

This that-REL anger made has was not Claudi it/*she was Simone

'The one who caused the trouble was not Claudi, it / *she was Simone.'

15. A reviewer points out that, since the post-copular XP in implementation (ii) is of propositional type (see diagram in (71)), one may expect that pronouns in post-copular position must be neuter, contrary to what we observe in example (i). However, as we saw in subsection 2.3 , the semantic analysis given in implementation (ii) must be coupled with a syntactic representation where the post-verbal constituent is a partially elided clause, as illustrated in (ii). Adopting this syntactic structure, implementation (ii) makes the right prediction that the feminine pronoun her should be allowed. The question remains as to why the neuter pronoun it is completely out, since the post-verbal clause -whether partially deleted or not- should in principle be able to pronominalize in neuter form in the structure in (iii). Let me point out, though, that this unsolved problem is independent of the present analysis of SSs, since it also obtains in question/answer pairs like (iv).

(i) We didn't believe that the girl Bob wanted to date was Mary, and in fact it was her/*it.

(ii) ... [the girl Bob wanted to date $]_{2}$ was Mary $\left._{1}\right]_{\text {It }}$ It $_{2}$ was $\mathrm{her}_{1} / * \mathrm{it}_{1}$ ].

(iii) ... [the girl Bob wanted to date $]_{2}$ was Mary $\left._{1}\right]_{3} . \mathrm{It}_{2}$ was $* \mathrm{it}_{3}$. 


\subsection{Coordination}

Coordination of a verb taking a CQ -e.g., know or guess - with an extensional verb is deviant. This is illustrated in (79), which sounds like a play on words (in fact, like a zeugma):

(79) * John guessed and kissed the winner of the Oscar for best actress.

Interestingly, specificational be is also illicit in coordination with an extensional predicate like have too much self-confidence. Example (80) is judged ungrammatical:

(80) * The person (/Who) John ${ }_{1}$ admires the most is himself ${ }_{1}$ and has too much self-confidence.

The fact that neither know nor be can share an argument with an extensional verb already argues for a unified analysis of know and be that differentiates them for extensional verbs. But, besides that, coordination brings support for implementation (ii) over implemenation (i). Consider (81), an example in which a syntactic node containing a regular intensional verb, look for, is coordinated with a syntactic node containing the extensional verb find. The sentence is perfectly grammatical under the de dicto reading:

(81) John is looking for but will not find a (/the best) secretary that speaks seven languages.

Sentence (81) shows that, although look for requires and intensional argument and find expects an extensional individual, the two verbs can share their argument in a coordinated structure. ${ }^{16}$ Presumably, some type-shifting operation is able to relate the intensionalized individual of look for (a property in Zimmermann (1992), an intensional generalized quantifier in Moltmann (1997), or perhaps an individual

(iv) Scenario: A is asking the same question to several people, one after the other.

A (to B): Which girl does Bob want to date?

$\mathrm{B}$ :

${ }_{\mathrm{IP}}^{\mathrm{Mary}} \mathrm{I}_{3}$

A (to C): Which girl does Bob want to date?

C:

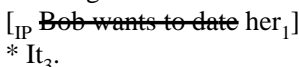

16. Example (81) has the syntactic representation in (i). We see that two functional projections are conjoined, and that the direct object $I_{N P}$ a (/the best) secretary that speaks seven languages] is Right-Node Raised in an A(cross)-T(he)-B(oard) fashion, leaving behind two traces $t_{l}$ that are exactly alike. Hence, semantically, the verbs look for and find share the same argument because they both apply to the semantic value of $t_{l}$. A regular intensional verb and an extensional verb can of course also share the same semantic subject, as shown in (ii).

(i) S-Str: John [ $\left[_{\mathrm{FP}}\right.$ is looking for $\left.\mathrm{t}_{1}\right]$ but $\left[_{\mathrm{FP}}\right.$ will not find $\left.\mathrm{t}_{1}\right]$ ] [a (/the best) secretary that speaks seven languages $]_{1}$.

(ii) A secretary that speaks seven languages was sought but not found. 
concept) to the extensional individual of find. But, then, why is coordination between CQs/SSs and extensional verbs impossible?

Implementation (ii) offers a line of explanation: the semantic argument of know and $b e$ is not an intensionalized individual, but a propositional concept. Whereas the difference between an intensionalized individual and an extensional individual can be overcome in (81), the difference between a proposition-like object and an extensional individual cannot be salvaged in (79)-(80). The argument of an extensional verb and the argument of know/be are simply too different in nature: the former is individual-like, the latter is propositional.

Under implementation (i), instead, the pattern in (79)-(81) is hard to explain. Take, for instance, the definite version of (81) John is looking for but will not find the best secretary that speaks seven languages. The NP the best secretary that speaks seven languages must provide a property $\langle\mathrm{e},\langle\mathrm{s}, \mathrm{t}\rangle\rangle$ as the argument of look for (following Zimmermann (1992)), and at the same time it must provide a plain individual of type e as the argument of find. If the difference between a property and an extensional individual can be overcome in (81), it is not clear why the difference between an individual concept $\langle\mathrm{s}$,e $\rangle$ and the corresponding extensional individual of type e cannot be overlooked in (79)-(80).

This coordination pattern is not an accident of English, but it is supported by crosslinguistic data from German, Finnish and Russian. In German, (82) sounds as if the speaker is trying to be funny or unexpected. Example (83) is ungrammatical without the subject $e r$ 'he'. That is, VP coordination is impossible in (83); two full sentences must be coordinated, the second one of which has the pronoun er 'he' referring to Rudi as its subject. Coordination of (verbal projections of) sucht 'seeks' and findet 'finds' is allowed, as in (84).
?? John hat die
Gewinnerin vorhergesagt und geküsst .
John has the-fem winner predicted
and kissed
'John predicted and kissed the winner.'

(83) Wen Rudi am meisten bewundert ist er selbst

Whom Rudi at most admires ist he self und *(er) hat auch zuviel Selbstvertrauen.

and $*$ (he) has also too-much self-confidence

'(The person) whom Rudi admires the most is himself and *(he) has too much self-confidence.'

(84) Der Jorge sucht und findet wahrscheinlich auch eine Sekretärin,

The Jorge seeks and finds probably also a secretary

die sieben Sprachen spricht.

that seven languages speaks

'Jorge is looking for and will probably also find a secretary that speaks seven languages.'

Finnish also prohibits coordination of CQs/SSs with extensional verbs, as in (85)-(86), while allowing for the coordination in (87): 
(85) * Jussi arvasi ja suuteli naispääosa-Oscarin voittajaa. Jussi-NOM guessed and kissed female-lead-oscar-GEN winner-PART 'John guessed and kissed the winner of the Oscar for best actress.'

(86) Se ketä Jussi ihailee eniten on hän itse, It-NOM whom Jussi-NOM admired most is he-NOM self-NOM, ja ?\# (hän) on liian itsevarma. and (she/he-NOM) is too self-confident

'The one Jussi admires the most is himself and ?\#(he) is too self-confident.'

(87) Jussi etsii, mutta ei tule löytämään, sihteeriä joka puhuu Jussi seeks but not will find secretary that speaks seitsemää kieltä. seven languages

'John is looking for but will not find a secretary that speaks seven languages.'

The same paradigm is found in Russian: (88) sounds like a joke, (89) is illformed, and (90) is grammatical.

(88) \# Vania ugadal i poceloval Oskarovskogo laureata premii luchshej John guessed and kissed Oscar laureate of-award to-best aktrise actress

'John guessed and kissed the winner of the Oscar for best actress.'

(89) *? Chelovek, kotorym Vania voshishchaets'a bol'she vsego eto on Person which-INSTR John admires most of-all this he sam i slishkom uveren $\mathrm{v}$ sebe. self and too-much is-sure in self.

'The person who John admires the most is himself and is too sure of himself.'

(90) Vania ishchet no ne najdet sekretaria, kotoryj by govoril na John looks-for but not will-find secretary who would speak in semi jazykah.

seven languages

'John is looking for but will not find a secretary that speaks seven languages.'

In sum, crosslinguistic coordination data support a unified analysis of CQs and SSs along the lines of implementation (ii). ${ }^{17}$

17. The three-fold coordination pattern cannot be fully tested in pro-drop languages like Catalan because, in the corresponding SS example, like (i), one cannot tell whether we have coordination of two VPs or coordination of two sentences with pro-drop of the second subject. Other than that, the rest of the pattern is as in the examples in the text: CQs cannot be coordinated with extensional 


\subsection{Matching effects in free relatives}

Hirschbühler-Rivero (1983a) note that (regular) free relatives in Catalan and in other languages must obey certain morpho-syntactic matching between the relative pronoun and the function of the entire free relative. Take the Catalan examples below. In (91), the relative pronoun qui 'who' and the entire free relative both function as direct objects of their verbs. Matching is satisfied and the structure is grammatical. The same happens in (92), where both the relative pronoun and the free relative have the same syntactic function and the same prepositional marking. In contrast, in (93), the relative pronoun is an adjunct PP whereas the free relative as a whole functions as direct object; this mismatch of syntactic function and morpho-syntactic marking leads to ungrammaticality. ${ }^{18}$

(91) Invito qui (/ la que) has invitat. (Hirschbühler-Rivero 1983a) I-invite who (/ the that) you-have invited. 'I invite (the person) who you have invited.'

verbs, as shown in (ii), and regular intensional verbs can share their argument with extensional ones, as in (iii).

(i) La persona que el Joan admira més és ell mateix i (pro) té massa The person that the Joan admires most is he himself and (pro) has too-much conficança en si mateix. confidence in SE himself.

'The person Joan admires the most is himself and (pro) has too much self-condifence.'

(ii) * En Joan va endevinar i besar la guanyadora de l'òscar a la millor The Joan AUX guess and kiss the winner of the-Oscar to the best actriu.

actress

'Joan guessed and kissed the winner of the Oscar for best actress.'

(iii) En Joan està buscant però no trobarà una secretària que parli

The Joan is looking-for but not will-find a secretary that speaks-SUBJ set idiomes.

seven languages

'Joan is looking for but will not find a secretary that speaks seven languages.'

18. A few clarifications are in order concerning the examples in this subsection. First, the original examples (91) and (93) from Hirschbühler-Rivero (1983a) contain the relative pronoun qui 'who', but the same holds for the free relative version with an overt article $l a$ 'the' and the relative pronoun que 'that', as noted in the parentheses. Second, the intended pronunciation of the CQ examples below places no stress on the relative pronouns qui 'who' (in (94)) and donde 'where' (in (100)), to distinguish them from the stressed interrogative pronouns qui 'who' and dónde 'where'. In both cases, the version with the sequence 'the' + relative pronoun is also included, leading to the same judgments. Finally, a reviewer points out that Hirschbühler-Rivero's (1983) example in (95) sounds odd. A parallel example that sounds completely natural to me is (i):

(i) No saps en el que t'estàs ficant.

Not you-know in the that REFL-you-are putting

'You don't know (the thing) into which you are getting yourself.'

I.e., 'You don't know what you are getting yourself into.' 
(92) Vaig ballar amb qui/ la que vaig venir. I-AUX dance with whom/ the that I-AUX come. 'I danced (with the person) with whom I came.'

(93) * Invito amb qui (/ la que) te n'aniràs. (Hirschbühler-Rivero 1983a)

I-invite with whom (/ the that) REFL you-will-leave.

'I invite (the person) with whom you'll leave.'

Hirschbühler-Rivero (1983b) further note that free relatives functioning as CQs are not subject to this matching requirement, witness the Catalan examples (94)-(95):

(94) Sé amb qui / la que te n'aniràs.

I-know with whom / the that REFL EN-you'll-leave.

'I know (epistemically) (the person) with whom you'll leave.'

(95) Observa en lo que ens vam posar. (Hirschbühler-Rivero 1983b) Observe in the that us we-AUX put

'Observe the (situation) into which we got ourselves.'

I.e., 'Observe what we got ourselves into.'

Interestingly, SSs pattern like CQs and unlike regular free relatives, that is, SSs do not obey this matching requirement: ${ }^{19}$

(96) Amb qui / la que vaig ballar va ser amb la Joana. With whom/ the that I-AUX dance AUX be with the Joana. '(The person) with whom I danced was with Joana.'

(97) En qui / el que més has de pensar és en tu mateix. In who / the that most you-have of think is in you self. '(The person) in whom you have to think most is in yourself.'

The same facts hold for Spanish. The free relative as a whole and the relative pronoun itself must match morpho-syntactically if the free relative functions as an argument of a regular extensional verb, as shown in (98)-(99). Matching between the two is not necessary when the free relative functions as a CQ or as a SS, as shown in (100)-(101):

19. Izvorski (2000) notes that, although regular free relatives in a topicalized position are not subject to matching either, regular free relatives in a post-verbal subject position must obey matching. SSs are free of matching effects regardless of whether they precede or follow the copula, as shown in (i):

(i) En tu mateix és en qui / el que més has de pensar.

In you self is in who / the that most you-have of think

'Yourself is who you have to think of most.' 
(98) Invito a quien / la que has invitado. I-invite A who / the that you-have invited. 'I invite (the person) who you have invited.'

(99) * Invito con quien / la que has bailado. I-invite with whom / the that you-have danced. 'I invite (the person) with whom you danced.'

(100) No saben donde / en lo que se menten. Not they-know where / in the that REFL they-put 'They don't know where / (the thing) into which they are putting themselves.'

I.e., 'They don't know what they are getting themselves into.'

(101) Con quien / la que bailé fue con Juana.

With whom / the that I-danced was with Joana.

'(The person) with whom I danced was Joana.'

Hence, empirical data on Catalan and Spanish free relatives argue for a unified analysis of CQs and SSs that distinguishes them from the extensional NPs in (91)-(93) and (98)-(99).

But we can still go further. Data on free relatives and matching effects not only argue for a unified analysis of CQs and SSs, they also support implementation (ii) of this unified analysis over implementation (i). Take the Catalan example (102) and in Spanish example (103), whose main verb is the regular intensional verb buscar 'look for'. We see that free relatives that function as (regular) intensional objects are subject to matching requirements too. This means, again, that CQs and SSs must be differentiated not only from extensional NPs but also from regular intensional NPs.

* Està buscant per qui / la que has vingut. He-is seeking for whom / the that you-have come 'He is seeking (the person) for whom you have come.'

* Está buscando con quien / la que has bailado. ${ }^{20}$
He-is seeking with whom / the that you-have danced
'He is seeking (the person) with whom you danced.'

This goal can be achieved under implementation (ii). In extensional and regular intensional free relatives, the relative pronoun receives case or prepositional marking from its own verb, and at the same time it inherits the case or preposi- 
tional marking assigned to the free relative as a whole. When the two markings disagree, the syntactic structure is ill-formed, as in (93), (99) and (102)-(103). But, in the case of CQs and SSs, the argument of the matrix verb know or be is ANS([[NP]]), which is a propositional argument. If clause-like constituents are exempt from case, or if we assume that the extra layer of structure introduced by ANS blocks case percolation, we can explain why no case marking conflict ever arises with CQs and SSs. Implementation (i), on the other hand, offers no line of explanation, since regular intensional arguments, CQs and SSs all receive the same structural analysis.

In sum, matching effects in Catalan and Spanish free relatives argue for a unified analysis of CQs and SSs within implementation (ii).

\section{Conclusions}

A unified intensional analysis of concealed question NPs with know and specificational subject NPs with be has been proposed in which the NP combines with an ANs(wer) operator to construct the intensional argument of the verb. First, following and developing Romero (2003), we noted that CQs with know and SSs with be display certain ambiguity absent in extensional contexts. Then, these two constructions are given an intensional analysis with two possible implementations. In implementation (i), the semantic contribution of the NP -of type $\langle\mathrm{s}, \mathrm{e}\rangle$ or $\langle\mathrm{s},\langle\mathrm{s}, \mathrm{e}\rangle\rangle-$ directly combines with the verb. In implementation (ii), the operator ANS intervenes between the verb and the NP, and the complex ANS(NP) -of type $\langle\mathrm{s},\langle\mathrm{s}, \mathrm{t}\rangle>-$ provides the argument of the verb. Three sets of data are then introduced in support of the unified analysis under implementation (ii). The first set of data, on gender in pronominalization, suggests that the argument of know and be, unlike that of regular intensional verbs like look for, is propositional in nature, thus supporting implementation (ii). Coordination examples constitute the second set of data, arguing that the argument of know/be is ontologically different from that of regular intensional verbs, as predicted under implementation (ii). Third and finally, matching effects in Catalan and Spanish free relatives suggest that an extra syntactic layer intervenes between know/be and their argument NP, as proposed in implementation (ii).

In the bigger picture, the choice between implementation (i) and implementation (ii) has important repercussions for the explanation of connectivity effects in specificational sentences. Recall from section 2.3 that implementations (i) and (ii) differ not only in the shape and type of the pre-copular constituent, but also in the syntactic structure the post-copular phrase. Whereas implementation (i) analyzes sentence (104) as having a post-copular NP, as in (105), implementation (ii) attributes to it a post-copular partially elided clause, as in (106).

(104) What he ate was potatoes.

(105) Implementation (i):

$\left[{ }_{\mathrm{NP}<\mathrm{s}, \mathrm{e}}>\right.$ What he ate $]$ was $\left[_{\mathrm{NPe}}\right.$ potatoes $]$ 
(106) Implementation (ii):

$[\mathrm{XP}<\mathrm{s},<\mathrm{s}, \mathrm{t}>$ANSwhatheate $]$ was $\left[_{\mathrm{IP}<\mathrm{s}, \mathrm{t}>}\right.$ potatoes $]$

In fact, the syntactic representations in implementations (i) and (ii) correspond to those of two important theories in the analysis of connectivity: the 'as is' account (Jacobson (1994), Sharvit (1999), Cecchetto (2000), Heller (2002)) and the question plus deletion account (Ross (1972), den Dikken et al. (2000), Ross (2000) and Schlenker (2003)), respectively. In the 'as is' account, the sentences (107) and (108) have the syntactic representations in (109), and connectivity effects arise through purely semantic - not syntactic- mechanisms. For example, variable binding connectivity in (108) -i.e., the semantic effect of understanding his as co-valued with the variable introduced by no boy-is not derived through LF c-command of no boy over his, but it is derived from analyzing the pre- and post-copular constituents as denoting functions of type $\langle e, e\rangle$, as spelled out in (110).

(107) The person he ${ }_{1}$ likes the most is himself . $_{1}$

(108) The woman no boy ${ }_{1}$ saw was his ${ }_{1}$ mother.

(109) 'As is' account:

a. $\left[_{\mathrm{NP}}\right.$ The person he $\mathrm{l}_{1}$ likes the most $]$ is $\left[_{\mathrm{NP}}\right.$ himself $\left.{ }_{1}\right]$

b. $\left[_{\mathrm{NP}}\right.$ The woman no boy ${ }_{1}$ saw $]$ was $\left[_{\mathrm{NP}}\right.$ his $_{1}$ mother $]$

(110) $\lg _{<\mathrm{e}, \mathrm{e}>}\left[\operatorname{Natural}(\mathrm{g}) \wedge \neg \exists \mathrm{x}_{\mathrm{e}}[\operatorname{boy}(\mathrm{x}) \wedge \operatorname{see}(\mathrm{x}, \mathrm{g}(\mathrm{x}))]\right]=\lambda \mathrm{y}_{\mathrm{e}} \cdot \mathrm{uz}_{\mathrm{e}}[\operatorname{mother}(\mathrm{z}, \mathrm{y})]$

In the question plus deletion account, instead, connectivity effects are syntactically derived. They arise from the syntactic representation of the post-copular constituent, which is a partially elided clause, as illustrated in (111). In this respect, the relation between the pre-copular and the post-copular constituents is parallel to that between questions and partially elided answers, as in (112).

(111) Question plus deletion account:

a. $\left[_{\mathrm{NP}}\right.$ The person he ${ }_{1}$ likes the most] is IIP $_{4}$ himself ${ }_{1}$

b. $\left[_{\mathrm{NP}}\right.$ The woman no boy ${ }_{1}$ saw ] was [IP $_{4}$

(112) a. A: Which person does he ${ }_{1}$ like the most?

B: He ${ }_{4}$ likes himself ${ }_{1}$ thest.

b. A: Which woman did no boy ${ }_{1}$ see?

B: ${ }_{4}$ his $_{1}$ mother.

In summary, the arguments presented in this paper in support of the semantic implementation (ii) also argue for the syntactic representation provided in the question plus deletion account and against the syntactic representation in the 'as is' account. As these two accounts give a different analysis of connectivity, the arguments in this paper indirectly yield support for the syntactic derivation of connec- 
tivity in the question plus deletion account and against the semantic derivation of connectivity in the 'as is' account.

\section{References}

Akmajian, Adrian (1970). «On Deriving Cleft Sentences from Pseudocleft Sentences». Linguistic Inquiry 1: 140-168.

Beck, Sigrid; Rullman, Hotze (1999). «A Flexible Approach to Exhaustivity in Questions». Natural Language Semantics 7: 249-298.

Büring, Daniel (1998). «Identity, Modality, and the Candidate Behind the Wall». In: Strolovitch, Devon; Lawson, Aaron (eds.). Proceedings of Semantics and Linguistic Theory VIII. Ithaca, NY: CLC, pp. 36-54.

Cecchetto, Carlo (2000). «Connectivity and Anti-connectivity in Pseudoclefts». In: Hirotani, Masako; Coetzee, Andries; Hall, Nancy; Kim, Ji-yung (eds.). Proceedings of the North East Linguistic Society 30. Amherst, MA: GLSA, pp. 137-151.

Chomsky, Noam (1986). Knowledge of language, its nature, origin and use. New York: Praeger.

den Dikken, Marcel; Meinunger, André; Wilder, Chris (2000). «Pseudoclefts and Ellipsis». Studia Linguistica 54: 41-89.

Farkas, Donka (1993). «Modal anchoring and NP scope». Linguistics Research Center, UC Santa Cruz, manuscript.

Heller, Daphna (2002). «On the Relations of Connectivity and Specificational Pseudoclefts». Natural Language Semantics 10: 243-284.

Heim, Irene (1979). «Concealed Questions». In: Bäuerle, Rainer; Egli, Urs; von Stechow, Arnim (eds.). Semantics from different points of view. Berling: Springer, pp. 51-60.

Heim, Irene (1994). «Interrogative Semantics and Karttunen's Semantics for know». In: Buchalla, Rhonna; Mittwoch, Anita (eds.). Proceedings of the Ninth Conference of the Israeli Association for Theoretical Linguistics. Jerusalem, pp. 128-144.

Heim, Irene; Kratzer, Angelika (1998). Semantics in Generative Grammar. Oxford: Blackwell.

Heycock, Caroline; Kroch, Anthony (1999). «Pseudocleft Connectednes: Implications for the LF interface level». Linguistic Inquiry 30: 365-397.

Heycock, Caroline; Kroch, Anthony (2002). «Topic, Focus, and Syntactic Representations». In: Mikkelsen, Line; Potts, Christopher (eds.). Proceedings of the West Coast Conference in Formal Linguistics 21. Somerville, MA: Cascadilla Press, pp. 141-165.

Higgins, Roger (1976). The Pseudo-cleft Construction in English. Indiana University Linguistics Club.

Hirschbühler, Paul; Rivero, María-Luisa (1983a). «Remarks on Free Relatives and Matching Phenomena». Linguistic Inquiry 14: 505-520.

Hirschbühler, Paul; Rivero, María-Luisa (1983b). «On Non-Matching Concealed Questions in Catalan and Spanish». Linguistic Review 2: 331-362.

Izvorski, Roumi (2000). Free Relatives and Related Matters. University of Pennsylvania, doctoral dissertation.

Jacobson, Pauline (1994). «Binding Connectivity in Copular Sentences». In: Harvey, Mandy; Santelmann, Lynn (eds.). Proceedings of Semantics and Linguistic Theory 4. Ithaca, NY: CLC, pp. 161-178. 
Karttunen, Lauri (1977). «Syntax and Semantics of Questions». Linguistics and Philosophy 1: 3-44.

Mikkelsen, Line (2004). «Specificational Subjects - a Formal Characterization and Some Consequences». Submitted to Acta Linguistica Hafniensia.

Moltmann, Frederike (1997). «Intensional Verbs and Quantifiers». Natural Language Semantics 5: 1-52.

Percus, Orin (2000). «Constraints on Some Other Variables in Syntax». Natural Language Semantics 8: 173-229.

Romero, Maribel (2003). «Concealed Questions and Specificational Subjects». Submitted and accepted for publication in Linguistics and Philosophy.

Ross, Haj (2000). «The Frozenness of Pseudoclefts - Towards an Inequality-based Syntax». University of North Texas, unpublished manuscript.

Schlenker, Philippe (2003). «Clausal Equations (A Note on the Connectivity Problem)». Natural Language and Linguistic Theory 21: 157-214.

Sharvit, Yael (1999). «Connectivity in Specificational Sentences». Natural Language Semantics 7: 299-339.

Zimmermann, Ede (1992). «On the proper treatment of opacity in certain verbs». Natural Language Semantics 1: 149-180. 